\title{
Pt-Cu/C and Pd Modified Pt-Cu/C Electrocatalysts for the Oxygen Reduction Reaction in Direct Methanol Fuel Cells
}

\author{
Emilia A. Carbonio, Flavio Colmati, Eduardo G. Ciapina, Maristela E. Pereira and \\ Ernesto R. Gonzalez*
}

Instituto de Química de São Carlos, Universidade de São Paulo, CP 780, 13560-970 São Carlos-SP, Brazil

\begin{abstract}
Neste trabalho, foram preparados diferentes eletrocatalisadores de $\mathrm{Pt}-\mathrm{Cu}$ e de $\mathrm{Pt}-\mathrm{Cu}$ modificados com Pd, suportados em carbono por meio da redução química de precursores de $\mathrm{Pt}, \mathrm{Cu}$ e Pd com borohidreto de sódio. A atividade eletrocatalítica frente à reação de redução de oxigênio foi estudada. A análise dos resultados de difração de raios $\mathrm{X}$ mostrou que há formação de liga. Com microscopia eletrônica de transmissão (TEM) foi observado que as nanopartículas metálicas estão bem distribuídas no suporte de carbono. Espectroscopia de absorção de raios $\mathrm{X}$ dispersiva (DXAS) foi empregada para compreender melhor as propriedades intrínsecas dos materiais. Os eletrocatalisadores foram caracterizados eletroquimicamente por voltametria cíclica em $\mathrm{H}_{2} \mathrm{SO}_{4} 0.5 \mathrm{~mol} \mathrm{~L}^{-1} \mathrm{e}$ a atividade eletrocatalítica destes foi estudada por meio de experimentos em estado estacionário em células a combustível de metanol direto (DMFC). A introdução de Pd ocasionou um aumento da atividade dos catalisadores de Pt-Cu. O melhor desempenho da DMFC foi obtido usando como cátodo o catalisador da liga de $\mathrm{Pt}_{50} \mathrm{Pd}_{40} \mathrm{Cu}_{10} / \mathrm{C}$ tratado termicamente a $500{ }^{\circ} \mathrm{C}$ em atmosfera de $\mathrm{H}_{2} / \mathrm{Ar}$.
\end{abstract}

In this work, different carbon supported Pt-Cu catalysts and Pd modified Pt-Cu catalysts were prepared by chemical reduction of $\mathrm{Pt}, \mathrm{Cu}$ and $\mathrm{Pd}$ precursors with sodium borohydride, and their electrocatalytic activity for the oxygen reduction reaction was studied. X-ray diffraction analysis indicated alloy formation. Transmission electron microscopy (TEM) showed that the metal nanoparticles are well-distributed on the carbon support. Dispersive X-ray absorption spectroscopy (DXAS) was used to achieve a better understanding of the intrinsic properties of the materials. The electrocatalysts were characterized electrochemically by cyclic voltammetry in $0.5 \mathrm{~mol} \mathrm{~L}^{-1} \mathrm{H}_{2} \mathrm{SO}_{4}$ and their electrochemical activity was studied with steady-state experiments in a direct methanol fuel cell (DMFC). The introduction of Pd led to an improvement of the catalytic activity of the $\mathrm{Pt}-\mathrm{Cu}$ catalysts. The best performance in a DMFC was obtained using, as cathode, $\mathrm{Pt}_{50} \mathrm{Pd}_{40} \mathrm{Cu}_{10} / \mathrm{C}$ alloy catalyst thermally treated at $500{ }^{\circ} \mathrm{C}$ in an $\mathrm{H}_{2} / \mathrm{Ar}$ atmosphere.

Keywords: oxygen reduction reaction, electrocatalysis, DMFC, cathodes

\section{Introduction}

Direct methanol fuel cells (DMFCs) are promising electrochemical energy converters for a variety of applications because of the system simplicity. The use of methanol as fuel has several advantages in comparison to hydrogen: it is a cheap liquid fuel, easily handled, transported and stored, with a high theoretical energy density. ${ }^{1}$ An additional advantage of DMFC is it does not require complex humidification and heat management

*e-mail: ernesto@iqsc.usp.br

\#Present address: Instituto de Química, Campus Samambaia, UFG, CP 131, 74001-970 Goiânia - GO, Brazil modules as in the hydrogen fed proton exchange membrane fuel cell (PEMFC) system. The dilute methanol/water mixture circulating around the DMFC provides the necessary humidification and heat management.

One of the main problems of DMFC's, which decreases the efficiency of conversion of the chemical energy of the methanol fuel to electrical energy, is the methanol crossover through the polymer electrolyte. ${ }^{2}$ Higher methanol tolerance is reported in the literature for non-noble metal cathode electrocatalysts based on chalcogenides ${ }^{3}$ and macrocycles of transition metals. ${ }^{4}$ These electrocatalysts have shown nearly the same activity for the oxygen reduction reaction (ORR) in the absence as well as in the presence of methanol. 
However in methanol free electrolytes, these materials did not reach the catalytic activity of carbon supported platinum. Developing sufficiently selective and active electrocatalysts for the cathodic reaction in DMFCs remains one of the tasks for further progress in this technology.

Earlier work showed that some platinum alloys with firstrow transition metals present a higher activity for the ORR than pure platinum in low temperature fuel cells operated directly with methanol. ${ }^{5}$ In general, metals such as V, Cr, $\mathrm{Co}$, Ti and $\mathrm{Ni}$, alloyed with platinum exhibit significantly higher electrocatalytic activities for the ORR than platinum alone in low temperature fuel cells. ${ }^{6}$ These Pt-alloy electrocatalysts improve both the cell performance and the nanoparticles resistance to sintering and coalescence under the operational conditions of the PEMFC. The enhanced ORR electrocatalysis has been ascribed to different factors such as the Pt-Pt inter-atomic distance, ${ }^{7}$ the surface area, ${ }^{8}$ the d-orbital vacancy, ${ }^{9}$ among others. Also, the observed increase in catalytic activity for increasing Pt particle sizes has been attributed to the reduced adsorption of $\mathrm{OH}$ on large particles because of the change in d-band occupancy related to changes in particle size. ${ }^{10}$

Some of the problems regarding preparation methods of carbon supported Pt-M alloys are difficulty in incorporating enough quantities of non-precious metal in the alloy and increase of particle size with respect to pure Pt. ${ }^{11}$ In this respect, electrocatalytic activity for some catalysts was found to increase with decreasing particle size, ${ }^{12}$ which was attributed to changes in distribution of surface atoms and crystal faces or in Pt d-band occupancy. ${ }^{13}$ Maillard et al. ${ }^{14}$ found that the electrocatalytic activity of $\mathrm{Pt} / \mathrm{C}$ catalysts for oxygen reduction in methanol-containing electrolytes increases when decreasing particle sizes, conversely to what they observed in methanol-free electrolytes. The mass activity for oxygen reduction in a methanol-containing electrolyte was found to increase continuously with decreasing particle size, not only because of the grater surface area of smaller particles, but also due to the existence of a significant particle size effect on the tolerance to methanol. This was attributed to a stronger adsorption of oxygenated species on smaller particles and to a particle shape effect modifying the methanol coverage. It has also been observed that $\mathrm{Pt}$ agglomeration causes a decay in catalyst mass activity owing to the decrease of platinum surface area. ${ }^{14}$

A common method of preparation of carbon supported Pt-M alloys consists in the deposition of the non-precious metal on previously formed carbon supported platinum, followed by alloying at high temperatures. ${ }^{15}$ This thermal treatment at high temperatures $\left(\geq 900{ }^{\circ} \mathrm{C}\right)$ gives rise to an undesired metal particle growth, by sintering and coalescence of platinum particles. ${ }^{16}$
In general, when Pt-based materials incorporate a non noble metal, some non noble metal oxide may remain at the catalyst surface or may be formed during cell operation due to oxidation at high potentials. Indeed, this affects the catalyst performance. In this sense, copper is a very interesting candidate to form alloys with platinum, because copper oxide was shown to have an important role in the activity for ORR. ${ }^{17,18}$ Because few reports exist on Pt-Cu alloys, ${ }^{19,20}$ in this work they have been prepared and their activity tested for ORR in a DMFC. In addition, it has been observed that the introduction of Pd in some binary and ternary catalysts led to an improvement in the electrocatalytic activity for ORR. ${ }^{21,22}$ Thus, the effect of introducing Pd into the Pt-Cu alloys was also studied under the same conditions.

\section{Experimental}

\section{Electrocatalysts preparation}

$\mathrm{Pt}-\mathrm{Cu} / \mathrm{C}$ and $\mathrm{Pt}-\mathrm{Pd}-\mathrm{Cu} / \mathrm{C}$ electrocatalysts were prepared with the addition of $0.04 \mathrm{~mol} \mathrm{~L}^{-1}$ sodium borohydride solution on high surface area carbon (Vulcan XC-72, Cabot, $240 \mathrm{~m}^{2} \mathrm{~g}^{-1}$ thermally pre-treated at $850^{\circ} \mathrm{C}$ under $\mathrm{Ar}$ atmosphere), under sonication. Solutions of chloroplatinic acid $\left(\mathrm{H}_{2} \mathrm{PtCl}_{6} \cdot 6 \mathrm{H}_{2} \mathrm{O}\right.$, Johnson Matthey), copper chloride $\left(\mathrm{CuCl}_{2} \cdot 2 \mathrm{H}_{2} \mathrm{O}\right.$, Merck) and for the ternary catalyst, palladium chloride $\left(\mathrm{PdCl}_{2}\right.$, Alfa Aesar) were slowly added to the carbon suspension. The supported catalysts were filtered, washed and dried at $80{ }^{\circ} \mathrm{C}$ in air for $1 \mathrm{~h}$. The materials were $20 \% \mathrm{~m} / \mathrm{m}$ metal on carbon. In order to test the effect of temperature on the catalysts they were submitted to thermal treatments at 500 and $900{ }^{\circ} \mathrm{C}$ under $\mathrm{Ar} / \mathrm{H}_{2}$ (4:1) atmosphere for $1 \mathrm{~h}$.

\section{Energy dispersive X-ray analysis (EDX)}

The mean atomic ratios of the $\mathrm{Pt}-\mathrm{Cu} / \mathrm{C}$ and $\mathrm{Pt}-\mathrm{Pd}-\mathrm{Cu} / \mathrm{C}$ catalysts were determined by EDX technique coupled to a scanning electron microscopy LEO Mod. 440 with a silicon detector with Be window, applying $20 \mathrm{kV}$.

$X$-ray diffraction $(X R D)$

X-ray diffractograms of the catalysts were obtained in a Huber diffractometer operating with $\mathrm{Cu} \mathrm{K} \alpha$ radiation $(\lambda=$ $0.15406 \mathrm{~nm}$ ). The monochromator used was a double crystal (Si 111). Those experiments were carried out in the D12AXRD1 X-ray diffraction beam line at Brazilian Synchrotron Light Laboratory, LNLS, Campinas-SP. Scans were done at $0.03^{\circ} \mathrm{min}^{-1}$ for $2 \theta$ values between 60 and 100 degrees. 
In order to estimate the mean crystallite size from XRD, Scherrer's equation was used,$^{23} T=0.9 \lambda / B \cos \theta$, where $\mathrm{T}$ is the average crystallite diameter, $\lambda$ is the wavelength of the $\mathrm{X}$-ray radiation $(0.154056 \mathrm{~nm}), \theta$ is the angle of the (220) peak and B is the value obtained dividing the (220) peak area by the maximum intensity. Both instrumental and strain line profile broadening were not taken into account in the calculation, assumed to be the same for all materials. Therefore, considering the comparative analysis of the present work, such approximations may not introduce significant errors in data analysis. The lattice parameters were obtained by refining the unit cell dimensions using FullProf program..$^{24}$

\section{Transmission electron microscopy (TEM)}

The samples for the TEM characterizations were prepared as follows: a carbon film was deposited onto a mica sheet and after release of the film in water it was placed onto the $\mathrm{Cu}$ grids ( 300 mesh and $3 \mathrm{~mm}$ diameter). The material to be examined was dispersed in water by sonication, placed onto the carbon film and left to dry. This technique was implemented at the microscopy laboratory of the LNLS using a HRTEM microscope JEOL, JEM 3010, URP, operating at $300 \mathrm{kV}$, with $0.17 \mathrm{~nm}$ resolution.

\section{Dispersive X-ray absorption spectroscopy (DXAS)}

The use of XAS to investigate catalysts has been reviewed several times in the literature. ${ }^{25}$ The in situ X-ray absorption time resolved spectroscopy measurements were performed at the $\mathrm{Pt}_{\mathrm{III}}$ absorption edge, using an appropriate spectro-electrochemical cell. ${ }^{26}$ The working electrodes consisted of pellets formed with the dispersed catalysts compacted with a PTFE dispersion (ca. $40 \mathrm{wt} . \%$ ) and containing $6 \mathrm{mg} \mathrm{cm}^{-2}$. The counter electrode was a Pt screen. This electrode was cut in the center, in order to allow the free passage of the X-ray beam. Dispersive $\mathrm{X}$-ray absorption (DXAS) experiments were done with the electrodes polarized at $0.1 \mathrm{~V}$ versus RHE and submitted to a linear sweep voltammetry at $10 \mathrm{mV} \mathrm{s}^{-1}$ from $0.1 \mathrm{~V}$ to $1.1 \mathrm{~V}$ versus $\mathrm{RHE}$. The results presented here correspond to the time resolved $\mathrm{X}$-ray absorption intensity versus the photon energy as function of potential.

\section{Electrode preparation for cyclic voltammetry and for tests in single DMFC}

Cyclic voltammetric experiments were carried out at room temperature $\left(c a .26^{\circ} \mathrm{C}\right)$ in a $0.5 \mathrm{~mol} \mathrm{~L}^{-1} \mathrm{H}_{2} \mathrm{SO}_{4}$ solution using an Ecochemie AUTOLAB PGStat 30 potentiostat. Potentials were measured using a reversible hydrogen electrode in the same solution. The working electrode was prepared by applying a thin layer (around $1 \mu \mathrm{m}$ thickness) of the supported catalyst dispersed in water on a glassy carbon disk according to a method already described. ${ }^{27}$ Briefly, a drop (approximately $45 \mu \mathrm{L}$ ) of a re-dispersed aqueous suspension containing about $1 \mathrm{mg} \mathrm{mL}^{-1}$ of catalyst was dropped on top of a glassy carbon disc of $0.348 \mathrm{~cm}^{2}$ embedded in PTFE, yielding around $56 \mu \mathrm{g} \mathrm{Pt} \mathrm{cm}{ }^{-2}$. After water evaporation, $40 \mu \mathrm{L}$ of a diluted Nafion ${ }^{\circledast}$ solution $(0.05$ wt.\%, in 1:1 water/methanol) was placed onto the dried catalyst material. The electrode was protected by a pure water droplet and then transferred to the electrochemical cell. No attempts were made to assess electrochemically the active area of the electrodes. Thus all currents were normalized by the Pt mass in the electrode (giving the so-called "mass activity").

In order to test the electrochemical behaviour in a single DMFC fed with methanol/oxygen, the electrocatalysts were used to make two layer gas diffusion electrodes (GDE). A diffusion layer was made with carbon powder (Vulcan XCR-72R) and $15 \mathrm{wt} . \% \mathrm{~m} / \mathrm{m}$ PTFE and applied over a carbon cloth (PWB-3, Stackpole). On top of this layer, the electrocatalyst was applied in the form of a homogeneous dispersion of $\mathrm{Pt}-\mathrm{Cu} / \mathrm{C}, \mathrm{Pt}-\mathrm{Pd}-\mathrm{Cu} / \mathrm{C}$ or $\mathrm{Pt} / \mathrm{C}, \mathrm{Nafion}^{\circledR}$ solution (5 wt.\%, Aldrich) and isopropanol (Merck). All electrodes were assembled to contain $1 \mathrm{mg} \mathrm{Pt} \mathrm{cm}{ }^{-2}$.

For the direct methanol single cells studies, the electrodes were hot pressed on both sides of a Nafion ${ }^{\circledR} 115$ membrane at $125^{\circ} \mathrm{C}$ and $50 \mathrm{~kg} \mathrm{~cm}^{-2}$ for $2 \mathrm{~min}$. Before using them, the Nafion ${ }^{\circledR}$ membranes were treated with a 3 wt. $\%$ $\mathrm{H}_{2} \mathrm{O}_{2}$ solution, washed and then treated with a $0.5 \mathrm{~mol} \mathrm{~L}^{-1}$ $\mathrm{H}_{2} \mathrm{SO}_{4}$ solution. The geometric area of the electrodes was $4.6 \mathrm{~cm}^{2}$, and the anode material was $20 \mathrm{wt} . \% \mathrm{Pt}_{1} \mathrm{Ru}_{1} / \mathrm{C}$ from E-TEK (Lot \#A1160825). The cell polarization data at $70{ }^{\circ} \mathrm{C} / 1 \mathrm{~atm} \mathrm{O}$ pressure and $90{ }^{\circ} \mathrm{C} / 3 \mathrm{~atm} \mathrm{O}$ pressure were obtained by circulating a $2 \mathrm{~mol} \mathrm{~L}^{-1}$ methanol aqueous solution at the anode.

Assuming that catalyst metal particles are individual crystallites and crystallites are spheres or cubes with negligible micro porosity, the specific areas $(\mathrm{S})$ were estimated using the expression: $\mathrm{S}=6 \times 10^{3} / \mathrm{pd}$ were $\mathrm{S}$ is the specific area $\left(\mathrm{m}^{2} \mathrm{~g}^{-1}\right), \rho$ is the density $\left(\mathrm{g} \mathrm{mL}^{-1}\right)$ of the crystallite and $d$ is the average crystallite diameter $(\mathrm{nm}){ }^{28,29}$ The density of the crystallites was determined with the expression: $\rho=\Sigma_{\mathrm{j}} \mathrm{x}_{\mathrm{j}}{ }^{*} \rho_{\mathrm{j}}$, were $\rho_{\mathrm{j}}$ is the density of metal $\mathrm{j}$ and $x$ is the mass ratio in the catalyst. The densities of pure platinum, palladium and copper used were $21.45,12.02$ and $8.920 \mathrm{~g} \mathrm{~mL}^{-1}$, respectively. The specific area calculated in this way is not the real electrochemically active area. 
However, this way of assessing the surface area gives a general idea of the surface atoms electrochemical activity while normalizing the currents with the calculated area when using the catalyst in a fuel cell. This is valid when comparing electrodes prepared in the same way. Even using the crystallite size instead of the true particle size, the approximation introduced is assumed to be the same in all cases.

\section{Results and Discussion}

\section{EDX analysis}

The average composition of the Pt-Cu and Pt-Pd-Cu alloy catalysts was evaluated by EDX analysis. For the $\mathrm{Pt}-\mathrm{Cu}$ alloys the $\mathrm{Cu}$ contents in various regions of the powder are considerably higher than the expected values from the precursor's concentration ratio used in the synthesis. Conversely, the Pt content is smaller than the expected value. The nominal and EDX compositions are shown in Table 1. The EDX compositions will be used throughout this work.

\section{XRD analysis}

\section{Pt-Cu/C catalysts}

Figure 1 shows the XRD patterns of the as-prepared and thermally treated carbon-supported $\mathrm{Pt}-\mathrm{Cu}$ alloy catalysts with different $\mathrm{Pt} / \mathrm{Cu}$ atomic ratios. As seen in Figure 1, all the XRD patterns present the main characteristic peaks of the face-centered cubic (fcc) crystalline Pt (JCPDS card, number 88-2343), ${ }^{30}$ in particular, the planes (220), (311) and (222), showing that all the alloy catalysts mainly resemble the single-phase disordered structure (solid solution). The diffraction peaks in the Pt-Cu alloy catalysts are slightly shifted to $2 \theta$ higher values with respect to the corresponding peaks in the $\mathrm{Pt} / \mathrm{C}$ catalyst. ${ }^{30}$ The shifts of the Pt peaks to higher angles reveal a lattice contraction, caused by $\mathrm{Cu}$ atoms incorporation, smaller than Pt atoms, in the fcc structure of Pt. The corresponding lattice parameters are shown in Table 1.

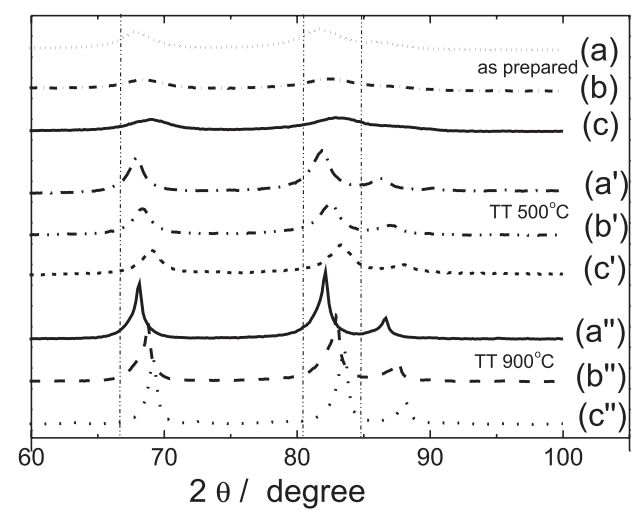

Figure 1. XRD diffractograms of carbon supported $20 \mathrm{wt} . \% \mathrm{Pt}-\mathrm{Cu} / \mathrm{C}$ catalysts as prepared and submitted to thermal treatment in a $\mathrm{H}_{2} / \mathrm{Ar}$ atmosphere at 500 and $900{ }^{\circ} \mathrm{C}$. Curves a, a' and a" are as prepared $\mathrm{Pt}_{70} \mathrm{Cu}_{30}$, $\mathrm{Pt}_{70} \mathrm{Cu}_{30}$ thermally treated at $500^{\circ} \mathrm{C}$ and $\mathrm{Pt}_{70} \mathrm{Cu}_{30}$ thermally treated at $900^{\circ} \mathrm{C}$, respectively. Curves b, b' and b" are as prepared $\mathrm{Pt}_{60} \mathrm{Cu}_{40}, \mathrm{Pt}_{60} \mathrm{Cu}_{40}$ treated at $500{ }^{\circ} \mathrm{C}$ and $\mathrm{Pt}_{60} \mathrm{Cu}_{40}$ treated at $900{ }^{\circ} \mathrm{C}$, respectively. Curves $\mathrm{c}, \mathrm{c}^{\prime}$ and $\mathrm{c} "$ are as prepared $\mathrm{Pt}_{50} \mathrm{Cu}_{50}, \mathrm{Pt}_{50} \mathrm{Cu}_{50}$ treated at $500{ }^{\circ} \mathrm{C}$ and $\mathrm{Pt}_{50} \mathrm{Cu}_{50}$ treated at $900^{\circ} \mathrm{C}$, respectively. The dashed vertical lines are the Bragg positions for pure Pt (JCPDS card, number 88-2343). ${ }^{30}$

In Figure 2 the lattice parameters are plotted as a function of the $\mathrm{Cu}$ content (from EDX composition) showing that up to 56 at.\% $\mathrm{Cu}$ the dependence is near linear. Thus, considering that $\mathrm{Pt}$ and $\mathrm{Cu}$ have the same crystal structure (fcc) it can be inferred that these materials follow Vegard's law.

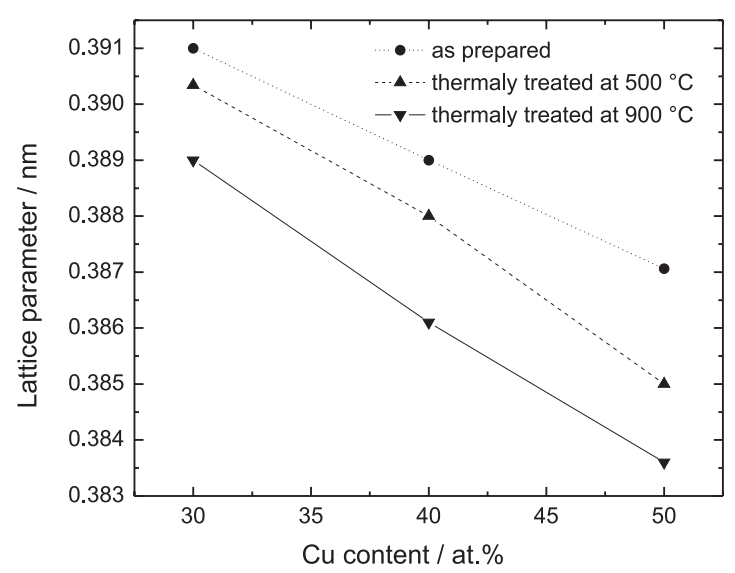

Figure 2. Lattice parameter of Pt-Cu catalysts as a function of $\mathrm{Cu}$ content (EDX composition).

Table 1. Metal crystallite sizes (d) and lattice constants (a) of the Pt-Cu and Pt-Pd-Cu catalysts

\begin{tabular}{lcccccc}
\hline Catalyst composition (Nominal ; EDX) & \multicolumn{2}{c}{ as prepared } & \multicolumn{2}{c}{ treated at $500{ }^{\circ} \mathrm{C}$} & \multicolumn{2}{c}{ treated at $900{ }^{\circ} \mathrm{C}$} \\
& $\mathrm{d}(\mathrm{nm})$ & $\mathrm{a}(\mathrm{nm})$ & $\mathrm{d}(\mathrm{nm})$ & $\mathrm{a}(\mathrm{nm})$ & $\mathrm{d}(\mathrm{nm})$ & $\mathrm{a}(\mathrm{nm})$ \\
\hline $\mathrm{Pt}_{90} \mathrm{Cu}_{10} ; \mathrm{Pt}_{70} \mathrm{Cu}_{30}$ & 3.2 & 0.391 & 5.7 & 0.390 & 0.0 & 0.389 \\
$\mathrm{Pt}_{80} \mathrm{Cu}_{20} ; \mathrm{Pt}_{60} \mathrm{Cu}_{40}$ & 2.7 & 0.389 & 5.1 & 0.388 & 7.7 & 0.386 \\
$\mathrm{Pt}_{70} \mathrm{Cu}_{30} ; \mathrm{Pt}_{50} \mathrm{Cu}_{50}$ & 2.6 & 0.387 & 4.8 & 0.385 & 9.9 & 0.383 \\
$\mathrm{Pt}_{80} \mathrm{Pd}_{10} \mathrm{Cu}_{10} ; \mathrm{Pt}_{60} \mathrm{Pd}_{20} \mathrm{Cu}_{20}$ & 3.2 & 0.389 & 10.2 & 0.388 & 24.8 & 0.386 \\
$\mathrm{Pt}_{60} \mathrm{Pd}_{30} \mathrm{Cu}_{10} ; \mathrm{Pt}_{50} \mathrm{Pd}_{40} \mathrm{Cu}_{10}$ & 3.3 & 0.389 & 15.1 & 0.388 & 29.3 & 0.387 \\
\hline
\end{tabular}


The mean size of the Pt-Cu alloy crystallites was estimated from XRD using Scherrer's equation. ${ }^{23}$ The values are given in Table 1 and show that the mean crystallite size of the prepared Pt-Cu/C alloy catalysts falls in the range 2-3 nm, then 5-6 nm when thermally treated at $500{ }^{\circ} \mathrm{C}$ and $7-10 \mathrm{~nm}$ when thermally treated at $900{ }^{\circ} \mathrm{C}$. It is worth to note that with the increase of $\mathrm{Cu}$ content in the Pt-Cu catalysts the mean crystallite size decreases, and this behavior is observed even for the catalysts submitted to thermal treatment at $500{ }^{\circ} \mathrm{C}$. On the other hand, for the catalyst thermally treated at $900{ }^{\circ} \mathrm{C}$ the crystallite size increases appreciably when the atomic ratio reaches 1:1. This may be due to a different temperature effect in the crystal growth in materials with high $\mathrm{Cu}$ contents, a subject that is beyond the scope of this work.

Considering that the catalysts studied here follow Vegard's law, tabulated values of the lattice parameters for $\mathrm{Pt}, \mathrm{Pt}_{50} \mathrm{Cu}_{50}$ and $\mathrm{Cu}, 0.39158 \mathrm{~nm}, 0.37769 \mathrm{~nm}$ and 0.36075 $\mathrm{nm}$ respectively, ${ }^{31}$ were used to calculate an "ideal" function for the variation of the lattice parameter with the atomic percentage of $\mathrm{Cu}$, at the solid solution (at.Cu $\mathrm{ss}_{\mathrm{ss}} \%$ ). For this calculation we assumed a linear dependence over the full range (0-100 at. $\left.\mathrm{Cu}_{\mathrm{ss}} \%\right)$ as the "ideal" one. The equation describing the linear dependence of the lattice parameter with the at. $\mathrm{Cu}_{\mathrm{ss}} \%$ at $\mathrm{Pt}: \mathrm{Cu}$ compositions for which Vegard's law is valid should be the same as the ideally calculated, independently of the occurrence of deviations at other compositions. Then, the at. $\mathrm{Cu}_{\mathrm{ss}} \%$ was calculated from the experimental values of the $\mathrm{Pt}-\mathrm{Cu}$ catalysts lattice parameters and the Pt:Cu atomic composition of the solid solution was estimated. The resulting values are summarized in Table 2. Also, it was possible to estimate the degree of alloy and the atomic copper oxide \%, as shown in Table 2.

Table 2. Pt: $\mathrm{Cu}$ atomic composition as calculated by Vegard's law, degree of alloy and copper oxide content for all the Pt-Cu catalysts

\begin{tabular}{lcccc}
\hline Pt-Cu catalyst / & $\begin{array}{c}\text { PT }: \mathrm{Cu} \\
\text { EDX composition } \\
\left({ }^{\circ} \mathrm{C}\right)\end{array}$ & $\begin{array}{c}\text { compostition } \\
\text { as calculated } \\
\text { by Vegard's } \\
\text { law }\end{array}$ & $\begin{array}{c}\text { Degree of } \\
\text { alloy/(\%) }\end{array}$ & $\begin{array}{c}\text { Copper } \\
\text { oxides/ } \\
\text { (at.\%) }\end{array}$ \\
\hline & none & $96: 4$ & 8.3 & 27.5 \\
$\mathrm{Pt}_{70} \mathrm{Cu}_{30}$ & 500 & $93: 7$ & 17.0 & 24.9 \\
\hline & 900 & $90: 10$ & 25.9 & 22.2 \\
\hline $\mathrm{Pt}_{60} \mathrm{Cu}_{40}$ & none & $90: 10$ & 16.7 & 33.3 \\
\hline & 500 & $87: 13$ & 23.0 & 30.8 \\
$\mathrm{Pt}_{50} \mathrm{Cu}_{50}$ & 900 & $80: 20$ & 37.0 & 25.2 \\
\hline & 500 & $77: 23$ & 29.9 & 35.1 \\
& 900 & $70: 30$ & 41.8 & 19.1 \\
\hline
\end{tabular}

It is clearly seen from Table 2 that the thermal treatment increases the degree of alloy, reducing the oxide content and leading to a more $\mathrm{Cu}$-rich alloy in all cases. Also, it is worth to note that comparing different catalysts (i.e. with different EDX composition) some tendencies may be found. For instance, the degree of alloy increases with total $\mathrm{Cu}$ content (from EDX composition), but also does the copper oxide contents. This is observed for all catalysts, except for the $\mathrm{Pt}_{50} \mathrm{Cu}_{50}$ thermally treated at $900{ }^{\circ} \mathrm{C}$, for which the oxide content is lower than for the other $\mathrm{Pt}_{50} \mathrm{Cu}_{50}$ catalysts. Again, this may be due to a different effect of the thermal treatment for materials with high $\mathrm{Cu}$ content. Meanwhile, it is important to keep in mind that the thermal treatment increases the degree of alloy by reducing the oxide content, but if we compare different catalysts submitted to the same thermal treatment, a higher degree of alloy does not necessary means less oxide content. This is an important fact when electrocatalytic properties of the different catalysts are discussed.

The effect of incorporation of $P d$ on the diffraction patterns

Figure 3 shows the XRD patterns of the as-prepared and thermally treated carbon-supported Pt-Cu catalysts that incorporate Pd. All the XRD patterns present the main characteristic peaks of the face-centered cubic (fcc) crystalline $\mathrm{Pt}$, as in the case of the $\mathrm{Pt}-\mathrm{Cu}$ catalysts. The diffraction peaks for the Pt-Pd-Cu alloy catalysts are slightly shifted to higher $2 \theta$ values with respect to the corresponding peaks in the $\mathrm{Pt} / \mathrm{C}$ catalyst,${ }^{30}$ indicating that the incorporation of $\mathrm{Cu}$ and $\mathrm{Pd}$ leads to a contraction of the lattice. The lattice parameters of the Pt-Pd-Cu alloy catalysts are given in Table 1, and show that the lattice parameter decreases with the thermal treatment, indicating a reduction of oxides and alloy formation. The crystallite sizes for the Pt-Pd-Cu catalysts are shown in Table 1. Recently, it was reported that the incorporation of Pd leads to an increase in the crystallite size. ${ }^{21}$ This effect can be seen here once the crystallite size of the thermally treated $\mathrm{Pt}_{50} \mathrm{Pd}_{40} \mathrm{Cu}_{10}$ catalyst (which has more $\mathrm{Pd}$ ) is larger than the thermally treated $\mathrm{Pt}_{60} \mathrm{Pd}_{20} \mathrm{Cu}_{20}$ catalysts. Apparently, this indicates that the qualitative and quantitative composition of Pt based nanocrystals determines the effect of the sintering and coalescence processes under thermal treatment.

\section{TEM}

Figures 4 and 5 show TEM images for the $\mathrm{Pt}_{60} \mathrm{Cu}_{40}$ catalysts thermally treated at 500 and $900{ }^{\circ} \mathrm{C}$, respectively, and illustrate the effect of thermal treatment on morphology. They show that the metal nanoparticles are well distributed on the carbon support. In Figure 4 it can be seen that there are few large particles (larger than $15 \mathrm{~nm}$ ) and 


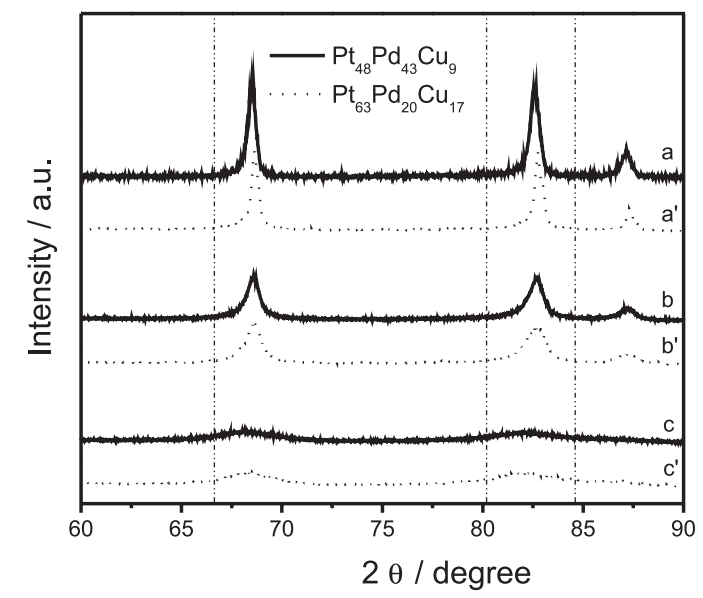

Figure 3. XRD diffractograms of carbon supported $20 \mathrm{wt}$ \% $\mathrm{Pt}-\mathrm{Pd}-\mathrm{Cu} / \mathrm{C}$ catalysts as prepared and submitted to thermal treatment in a $\mathrm{Ar} / \mathrm{H}_{2} 4: 1$ atmosphere at 500 and $900{ }^{\circ} \mathrm{C}$. Curves a and a' are the Pt-Pd-Cu catalysts thermally treated at $900{ }^{\circ} \mathrm{C}$. Curves b and b' are the Pt-Pd-Cu catalysts thermally treated at $500{ }^{\circ} \mathrm{C}$. Curves $\mathrm{c}$ and c' are the as prepared catalysts. The dashed vertical lines are the Bragg positions for pure Pt (JCPDS card, number 88-2343). ${ }^{30}$

several particles of small size (around $5 \mathrm{~nm}$ ). On the other hand, for the $\mathrm{Pt}_{60} \mathrm{Cu}_{40}$ catalyst thermally treated at $900{ }^{\circ} \mathrm{C}$ (Figure 5) there are few small particles and many large particles, in agreement with the tendency observed from the mean crystallite sizes determined from XRD, which is indicative of particle agglomeration and/or crystal growth with thermal treatment.

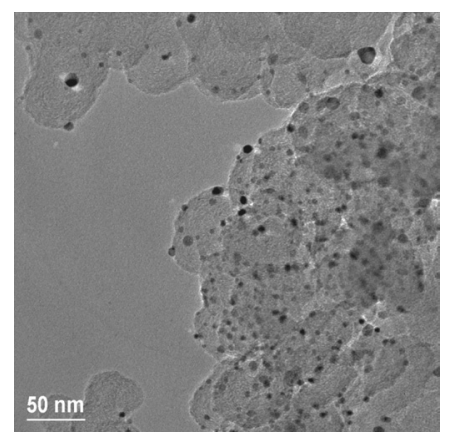

Figure 4. TEM micrographs of the $\mathrm{Pt}_{60} \mathrm{Cu}_{40} / \mathrm{C}$ catalyst prepared by chemical reduction with sodium borohydride and thermally treated at $500{ }^{\circ} \mathrm{C}$ in a $\mathrm{Ar} / \mathrm{H}_{2} 4: 1$ atmosphere.

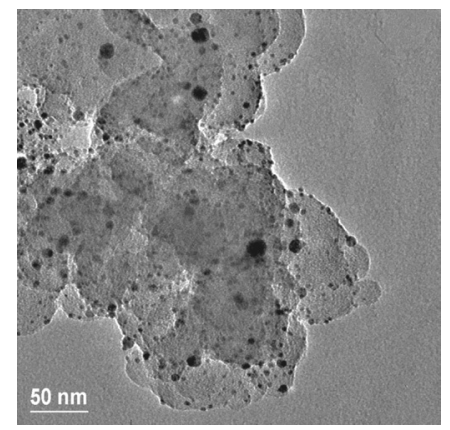

Figure 5. TEM micrograph of the $\mathrm{Pt}_{60} \mathrm{Cu}_{40} / \mathrm{C}$ catalyst prepared by chemical reduction with sodium borohydride and thermally treated at $900{ }^{\circ} \mathrm{C}$ in a $\mathrm{Ar} / \mathrm{H}_{2}$ 4:1 atmosphere.
Considering the materials that incorporate $\mathrm{Pd}$, the $\mathrm{Pt}_{50} \mathrm{Pd}_{40} \mathrm{Cu}_{10}$ catalyst thermally treated at $900^{\circ} \mathrm{C}$ has larger particles than the one thermally treated at $500{ }^{\circ} \mathrm{C}$, as well as bigger agglomerates $(10-40 \mathrm{~nm})$ caused by sintering and coalescence at high temperatures (not shown). Agglomeration is an undesired consequence of high temperature thermal treatments, because it causes a decrease in the active catalyst surface area.

\section{$D X A S$}

There is no doubt that the electronic properties of alloy catalysts are very important in determining the activity, and one of the ways to probe the electronic structure is through XAS experiments. In this work an initial evaluation of electronic effects on Pt-Cu catalysts was carried out by performing DXAS experiments with the Pt-Cu catalysts and Figure 6 shows the results for the as prepared $\mathrm{Pt}_{70} \mathrm{Cu}_{30}$ catalyst. The intensity of the white line is strong at low and high electrode potentials and has less intensity in the double layer region. In this region there is a minimum of adsorbed species on the electrode. At high potentials, the formation of adsorbed $\mathrm{OH}$ species increases on the catalyst surface, reducing the occupancy of $\mathrm{Pt} \mathrm{d}$-band which is reflected in an increase of the intensity of the white line. However, in this region of high potentials the white line in the $\mathrm{Pt}_{70} \mathrm{Cu}_{30}$ material is not as intense as on pure platinum (not shown) which is a clear indicator that the presence of $\mathrm{Cu}$ in the catalyst reduces the emptying of the Pt d-band. Similar results, not shown here, were observed with the $\mathrm{Pt}_{60} \mathrm{Cu}_{40}$ and $\mathrm{Pt}_{50} \mathrm{Cu}_{50}$ catalysts. The fact that the increase in the white line is not very pronounced in the presence of $\mathrm{Cu}$ indicates that the catalyst has a weak tendency to form oxides as potential increases. This effect improves the ORR kinetics, because it favours molecular oxygen adsorption on a surface where the competition for surface sites is less pronounced. Ressler et $a .^{32}$ showed by DXAS that the reduction of $\mathrm{CuO} / \mathrm{ZnO}$ (70 at. $\% \mathrm{Cu}, 30$ at. $\% \mathrm{Zn}$ ) to $\mathrm{Cu} / \mathrm{ZnO}$ in an 8 vol. $\% \mathrm{H}_{2}$ atmosphere is a function of the temperature, and they found that $\mathrm{Cu}$ is formed at around $220^{\circ} \mathrm{C}$. So, the intensity of white line decreases when the treatment temperature is higher than $220{ }^{\circ} \mathrm{C}$. In the present work the catalysts were thermally treated at 500 and $900{ }^{\circ} \mathrm{C}$ in an atmosphere with 20 vol. \% of $\mathrm{H}_{2}$, and alloying was not complete, indicating that some copper remains as oxide, as can be seen in Table 2. Lee et al. ${ }^{17}$ found that $\mathrm{PtCuO}$ catalysts prepared by rf sputtering and used as cathode catalysts, increased the power performance of a DMFC up to $25 \%$ in comparison with that with an unmodified Pt cathode. Also, Nabae et al. ${ }^{18}$ studied the performance of a $\mathrm{Cu} / \mathrm{C}$ cathode in a PEMFC. They proposed that the $\mathrm{Cu}^{2+}$ species should function as adsorption sites for 
molecular oxygen, increasing the concentration of $\mathrm{O}_{2}$ on the cathode. These observations suggest that the presence of some $\mathrm{Cu}$ oxide should enhance the performance of the catalysts towards the ORR.

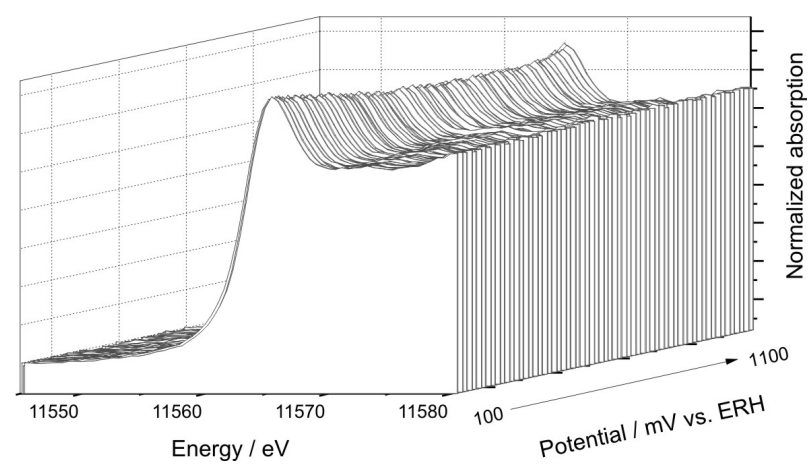

Figure 6. Dispersive X-ray absorption plots at the Pt edge (13564 eV) as a function of the electrode potential. From 0.1 to $1.1 \mathrm{~V} v s$. RHE at $10 \mathrm{mV} \mathrm{s}^{-1}$.

\section{Electrochemical experiments}

\section{Pt-Cu/C catalysts}

Figures 7 to 9 show the results of repetitive cyclic voltammetry $(\mathrm{CV})$ for the three $\mathrm{Pt}-\mathrm{Cu}$ catalysts submitted to thermal treatments at 500 and $900^{\circ} \mathrm{C}$. In general, they show a similar behaviour to that observed for carbon supported Ptbased nanocatalysts, exhibiting the three main characteristic regions of hydrogen adsorption/desorption, double layer and oxide/hydroxide formation. Potential cycling induces changes in the surface structure/composition of the alloy and, as the potential is swept repeatedly between 0.05 and $1.2 \mathrm{~V}$, the $\mathrm{CV}$ profile approaches the expected profile of carbon-supported pure platinum nanoparticles. Some small differences can be observed for the catalyst thermally treated at $900{ }^{\circ} \mathrm{C}$ if compared to that treated at $500{ }^{\circ} \mathrm{C}$, specially in the hydrogen adsorption/desorption region. These differences are related to the different degree of alloy because, as XRD analysis showed, an increase in the temperature of the thermal treatment increases the degree of alloy of the catalysts and these structural differences lead to different $\mathrm{CV}$ profiles.

\section{DMFC tests}

In order to evaluate and compare the activity of the $\mathrm{Pt}-\mathrm{Cu}$ catalysts, tests were carried out under stationary state conditions in single direct methanol fuel cells. Being the cathode catalyst the only different element among the cells, the differences in single cell performance with different cathode catalysts reflect the different activity of those catalysts toward the ORR in the presence of crossover methanol.

There are in general two ways of expressing the catalytic activity: the mass activity (MA), were the current

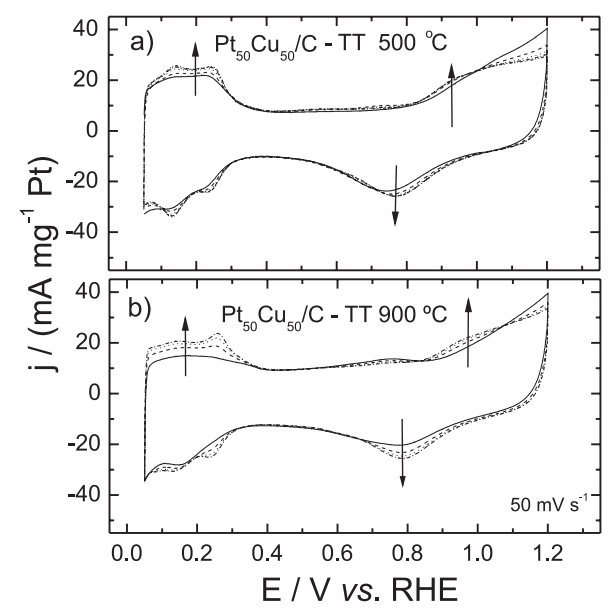

Figure 7. Cyclic voltammograms obtained in $0.5 \mathrm{~mol} \mathrm{~L}^{-1} \mathrm{H}_{2} \mathrm{SO}_{4}$ at $50 \mathrm{mV} \mathrm{s}^{-1}$, for the $\mathrm{Pt}_{50} \mathrm{Cu}_{50}$ catalysts thermally treated at (a) $500^{\circ} \mathrm{C}$ and (b) $900{ }^{\circ} \mathrm{C}$; Pt loading of $56 \mu \mathrm{g} \mathrm{cm}^{-2}$. Arrows indicate increasing number of cycles (from 5 to 20 ).

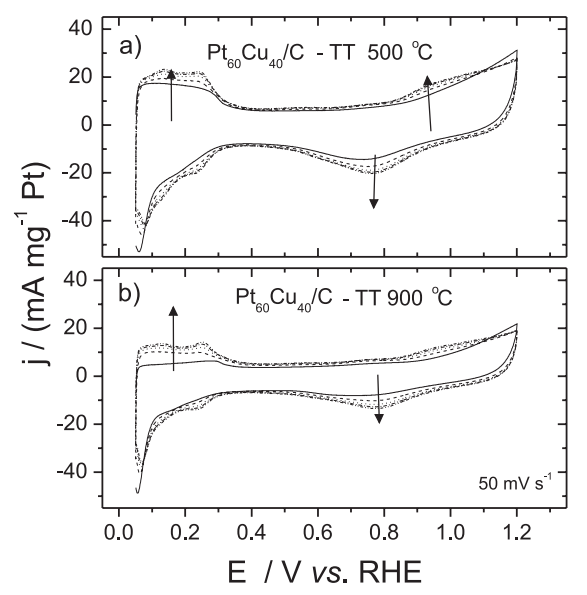

Figure 8. Cyclic voltammograms obtained in $0.5 \mathrm{~mol} \mathrm{~L}^{-1} \mathrm{H}_{2} \mathrm{SO}_{4}$ at $50 \mathrm{mV} \mathrm{s}^{-1}$, for the $\mathrm{Pt}_{60} \mathrm{Cu}_{40}$ catalysts thermally treated at (a) $500^{\circ} \mathrm{C}$ and (b) $900{ }^{\circ} \mathrm{C}$; Pt loading of $56 \mu \mathrm{g} \mathrm{cm}^{-2}$. Arrows indicate increasing number of cycles (from 5 to 20 ).

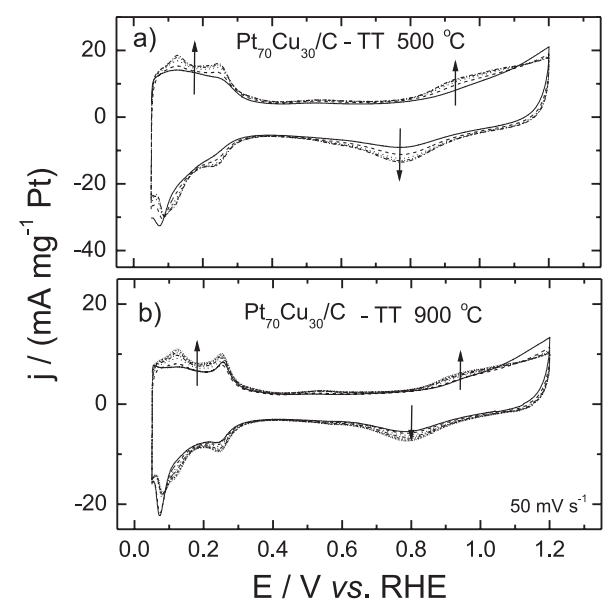

Figure 9. Cyclic voltammograms obtained in $0.5 \mathrm{~mol} \mathrm{~L}^{-1} \mathrm{H}_{2} \mathrm{SO}_{4}$ at $50 \mathrm{mV} \mathrm{s}^{-1}$, for the $\mathrm{Pt}_{70} \mathrm{Cu}_{30}$ catalysts thermally treated at (a) $500^{\circ} \mathrm{C}$ and (b) $900{ }^{\circ} \mathrm{C}$; Pt loading of $56 \mu \mathrm{g} \mathrm{cm}^{-2}$. Arrows indicate increasing number of cycles (from 5 to 20 ). 
is normalized by the Pt mass, and the specific activity (SA), were the current is normalized by the catalyst surface area. ${ }^{19}$ The first one has practical implications in fuel cells, since the electrode cost depends largely on the Pt contents. The second one, although the calculated area is not the real surface area, gives an idea about the electrocatalytic activity of the atoms at the surface of the catalyst. Therefore, assessing both the MA and the SA it should be possible to: $i$ ) know which catalyst has a better performance in a DMFC from a practical point of view (MA) and ii) make an approximate assessment if this is due to a better electrocatalytic activity of the surface atoms (SA) or is just due to differences in real surface area, or other effects. Although the SA values determined here are approximations, they are a useful tool when comparing materials prepared by the same method and treated under similar conditions. The values of the specific areas (S) and the density of crystallites for the Pt-Cu catalysts are shown in Table 3.

Table 3. Density and specific area (SA) of the catalysts

\begin{tabular}{|c|c|c|c|}
\hline $\begin{array}{l}\text { Catalyst EDX } \\
\text { Composition }\end{array}$ & $\begin{array}{l}\text { Thermal } \\
\text { Treatment }\end{array}$ & $\begin{array}{l}\text { Density/ } \\
\left(\mathrm{g} \mathrm{cm}^{-3}\right)\end{array}$ & $\begin{array}{c}\text { Specific area/ } \\
\left(\mathrm{m}^{2} \mathrm{~g}^{-1}\right)\end{array}$ \\
\hline $\mathrm{Pt}_{70} \mathrm{Cu}_{30}$ & $\begin{array}{c}\text { None } \\
\text { TT } 500^{\circ} \mathrm{C} \\
\text { TT } 900{ }^{\circ} \mathrm{C}\end{array}$ & 19.7 & $\begin{array}{l}95.3 \\
52.9 \\
37.9\end{array}$ \\
\hline $\mathrm{Pt}_{60} \mathrm{Cu}_{40}$ & $\begin{array}{c}\text { None } \\
\text { TT } 500^{\circ} \mathrm{C} \\
\text { TT } 900{ }^{\circ} \mathrm{C}\end{array}$ & 19.2 & $\begin{array}{c}114.9 \\
61.1 \\
40.8\end{array}$ \\
\hline $\mathrm{Pt}_{50} \mathrm{Cu}_{50}$ & $\begin{array}{c}\text { None } \\
\text { TT } 500^{\circ} \mathrm{C} \\
\text { TT } 900{ }^{\circ} \mathrm{C}\end{array}$ & 18.3 & $\begin{array}{c}126.0 \\
100.5 \\
33.0\end{array}$ \\
\hline $\mathrm{Pt}_{60} \mathrm{Pd}_{20} \mathrm{Cu}_{20}$ & $\begin{array}{c}\text { None } \\
\text { TT } 500{ }^{\circ} \mathrm{C} \\
\text { TT } 900{ }^{\circ} \mathrm{C}\end{array}$ & 19.25 & $\begin{array}{l}97.4 \\
30.5 \\
12.6\end{array}$ \\
\hline $\mathrm{Pt}_{50} \mathrm{Pd}_{40} \mathrm{Cu}_{10}$ & $\begin{array}{c}\text { None } \\
\text { TT } 500^{\circ} \mathrm{C} \\
\text { TT } 900{ }^{\circ} \mathrm{C}\end{array}$ & 17.93 & $\begin{array}{c}101.7 \\
22.2 \\
11.4\end{array}$ \\
\hline Pt/ C E-TEK & & 21.45 & 97.0 \\
\hline
\end{tabular}

\section{$\mathrm{Pt}-\mathrm{Cu} / \mathrm{C}$ catalysts}

Figures 10a and $10 \mathrm{~b}$ show the polarization curves in terms of the SA for the as prepared and thermally treated at 500 and $900{ }^{\circ} \mathrm{CPt}_{70} \mathrm{Cu}_{30}$ cathode catalysts with the cell operating at 70 and $90{ }^{\circ} \mathrm{C}$, respectively. The results with $\mathrm{Pt} / \mathrm{C}$ are included for comparison.

The catalysts treated at $900{ }^{\circ} \mathrm{C}$ show an increase of particle size, as discussed above, and also show the higher SA. This could be due to a particle size effect with more favorable d-band occupancy for the ORR. The observed increase in catalytic activity for the ORR when increasing particle sizes has been ascribed to the reduced strength of adsorption of oxygenated species on large particles,
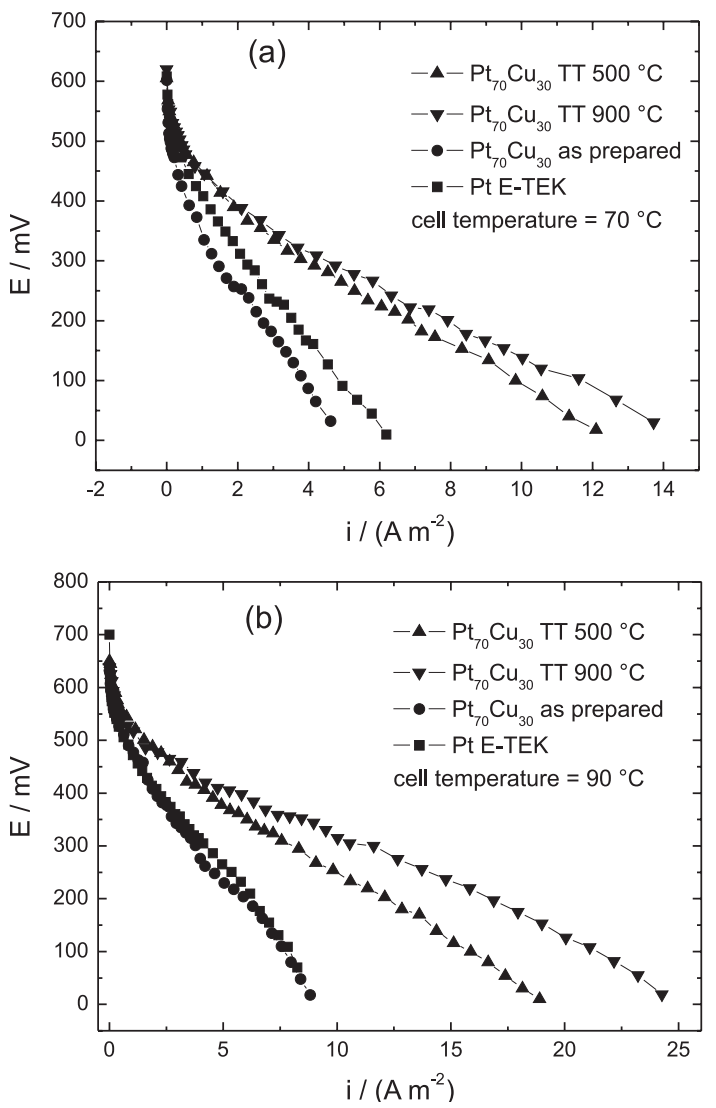

Figure 10. Cell potential vs. Current density in DMFC, in terms of SA. Cathode $\mathrm{Pt}_{70} \mathrm{Cu}_{30}$ as prepared; treated at 500 and $900{ }^{\circ} \mathrm{C}$ in $\mathrm{Ar} / \mathrm{H}_{2} 4: 1$ for 1h. Anode $\mathrm{Pt}_{50} \mathrm{Ru}_{50}$ from E-TEK. $1 \mathrm{~mol} \mathrm{~L}^{-1}$ methanol. (a) $70^{\circ} \mathrm{C}$; (b) $90^{\circ} \mathrm{C}$.

because the d-band vacancy decreases. Thus, the reduction of intermediate oxygenated species on the surface of the catalyst becomes easier. ${ }^{14,33}$

The thermal treatment also has an important effect because it reduces some $\mathrm{Cu}$ oxides and increases the degree of alloy (Table 2). This last effect may induce a modification of the electronic state, besides reducing de Pt-Pt distance, favoring the adsorption of molecular oxygen. Figures 11a and $11 \mathrm{~b}$ show the polarization curves in a DMFC in terms of the $\mathrm{SA}$ for $\mathrm{Pt}_{50} \mathrm{Cu}_{50}$, as prepared and thermally treated, with the cell operating at 70 and $90{ }^{\circ} \mathrm{C}$ respectively. The catalyst treated at $900{ }^{\circ} \mathrm{C}$ shows the best activity, as observed also for the $\mathrm{Pt}_{70} \mathrm{Cu}_{30}$ catalysts. However, the effect of a larger amount of copper is not beneficial, as observed by the fact that the performance of the catalyst thermally treated at $500{ }^{\circ} \mathrm{C}$ falls below that of $\mathrm{Pt} / \mathrm{C}$ in the case of the $\mathrm{Pt}_{50} \mathrm{Cu}_{50}$ catalyst. From Table 2, it should be noted that, for the $\mathrm{Pt}_{50} \mathrm{Cu}_{50}$ catalyst thermally treated at $500{ }^{\circ} \mathrm{C}$, the amount of copper oxides is approximately 35 at. \%. This is higher than the amount for $\mathrm{Pt}_{50} \mathrm{Cu}_{50}$ catalyst thermally treated at $900^{\circ} \mathrm{C}$, and for the $\mathrm{Pt}_{70} \mathrm{Cu}_{30}$ catalyst thermally treated at $500^{\circ} \mathrm{C}$ and $900^{\circ} \mathrm{C}$, being their estimated content of oxides approximately 19 at. $\%$, 25 at. $\%$ and 22 at.\%, respectively. 

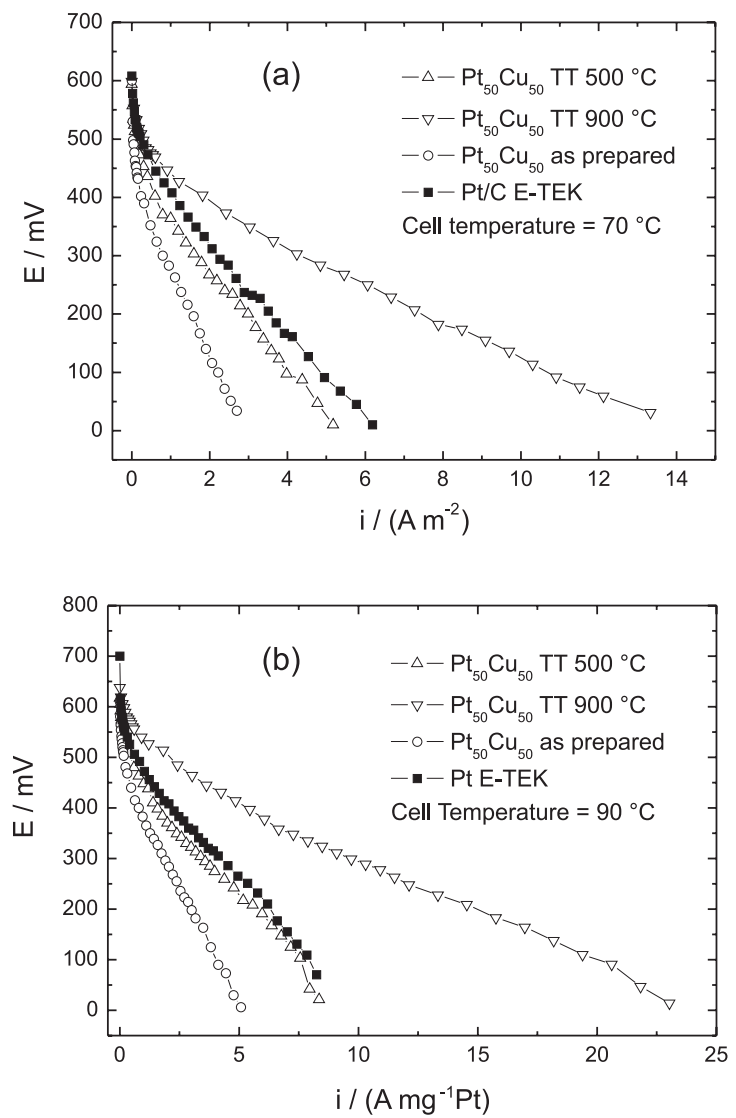

Figure 11. Cell potential vs. current density in a DMFC, in terms of SA. Cathode $\mathrm{Pt}_{50} \mathrm{Cu}_{50}$ as prepared; thermally treated at 500 and $900{ }^{\circ} \mathrm{C}$ in $\mathrm{Ar} / \mathrm{H}_{2}$ 4:1 for $1 \mathrm{~h}$. Anode $\mathrm{Pt}_{50} \mathrm{Ru}_{50}$ from E-TEK. 1 mol L-1 methanol. (a) $70^{\circ} \mathrm{C}$; (b) $90{ }^{\circ} \mathrm{C}$.

Considering the mass activity, Figures $12 \mathrm{a}$ and $12 \mathrm{~b}$ show the polarization curves in a DMFC for the $\mathrm{Pt}_{70} \mathrm{Cu}_{30}$ catalysts, at 70 and $90{ }^{\circ} \mathrm{C}$ respectively. The best MA was obtained with the catalyst thermally treated at $500{ }^{\circ} \mathrm{C}$. The larger particle size, thus lower specific area, for the catalyst thermally treated at $900{ }^{\circ} \mathrm{C}$ is the reason for the lower MA for this catalyst. The as prepared catalyst, even presenting a larger specific area, shows both a low MA and a low SA. This could be due to a greater amount of oxides present on the catalyst surface. The $\mathrm{PtCuO}$ catalyst prepared by Lee and co-workers ${ }^{17}$ had 8 at.\% of $\mathrm{CuO}$. It may be speculated that there must be a critical amount of copper oxide beyond which the catalytic activity of the catalyst begins to decrease instead of increase. This means that the presence of low amounts of $\mathrm{CuO}$ on the catalyst's surface may inhibit methanol oxidation ${ }^{17}$ and provide adsorption sites for oxygen, ${ }^{18}$ but on the other hand, a larger amount of these oxides on the catalyst's surface produces a decrease in the performance of the catalyst, because the oxide covers active sites of the metal surface. The thermal treatment in a hydrogen atmosphere reduces some of the copper oxides, thus "cleaning" the surface of the catalysts.
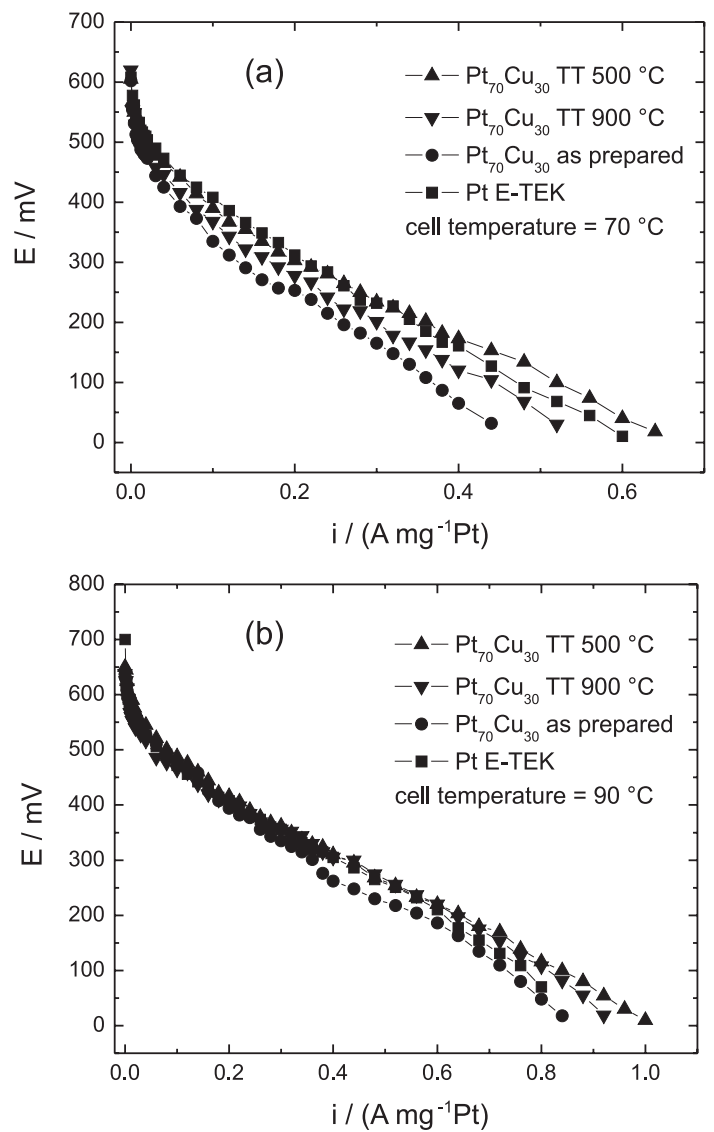

Figure 12. Cell potential vs. Current density in DMFC, in terms of MA. Cathode $\mathrm{Pt}_{70} \mathrm{Cu}_{30}$ as prepared; thermally treated at 500 and $900{ }^{\circ} \mathrm{C}$ in $\mathrm{Ar} / \mathrm{H}_{2}$ 4:1 for $1 \mathrm{~h}$. Anode $\mathrm{Pt}_{50} \mathrm{Ru}_{50}$ from E-TEK. 1 mol L-1 methanol. (a) $70{ }^{\circ} \mathrm{C}$; (b) $90{ }^{\circ} \mathrm{C}$

Figures $13 \mathrm{a}$ and $13 \mathrm{~b}$ show the polarization curves in a DMFC in terms of the MA for the $\mathrm{Pt}_{50} \mathrm{Cu}_{50}$ catalysts, at 70 and $90{ }^{\circ} \mathrm{C}$ respectively. It can be seen that in terms of MA the performance of the $\mathrm{Pt}_{50} \mathrm{Cu}_{50}$ catalysts is inferior to that of Pt E-TEK. In terms of $\mathrm{SA}$ the $\mathrm{Pt}_{50} \mathrm{Cu}_{50}$ thermally treated at $900{ }^{\circ} \mathrm{C}$ catalyst shows a better activity than $\mathrm{Pt} / \mathrm{C}$ (Figure 11), probably due to a particle size effect, an electronic effect (related to the first one), a more favorable Pt-Pt distance, and/or a smaller copper oxide content. However, the specific area is too small, so the MA for this catalyst is very low. The $\mathrm{Pt}_{60} \mathrm{Cu}_{40}$ catalysts showed a behavior similar to that of the $\mathrm{Pt}_{50} \mathrm{Cu}_{50}$ and the results are not shown here.

For all the $\mathrm{Pt}: \mathrm{Cu}$ compositions, the best values of MA (the ones of practical relevance) were obtained with the catalysts thermally treated at $500{ }^{\circ} \mathrm{C}$. Figures $14 \mathrm{a}$ and $14 \mathrm{~b}$ and $15 \mathrm{a}$ and $15 \mathrm{~b}$ show the effect of the $\mathrm{Cu}$ content in the catalysts treated at $500^{\circ} \mathrm{C}$ in terms of both SA (Figure 14) and MA (Figure 15). The $\mathrm{Pt}_{70} \mathrm{Cu}_{30}$ material presents the best values of SA and MA in the DMFC. This could be due to a favorable combination of low oxide content and a favorable $\mathrm{Pt}: \mathrm{Cu}$ ratio. The maximum power density in 

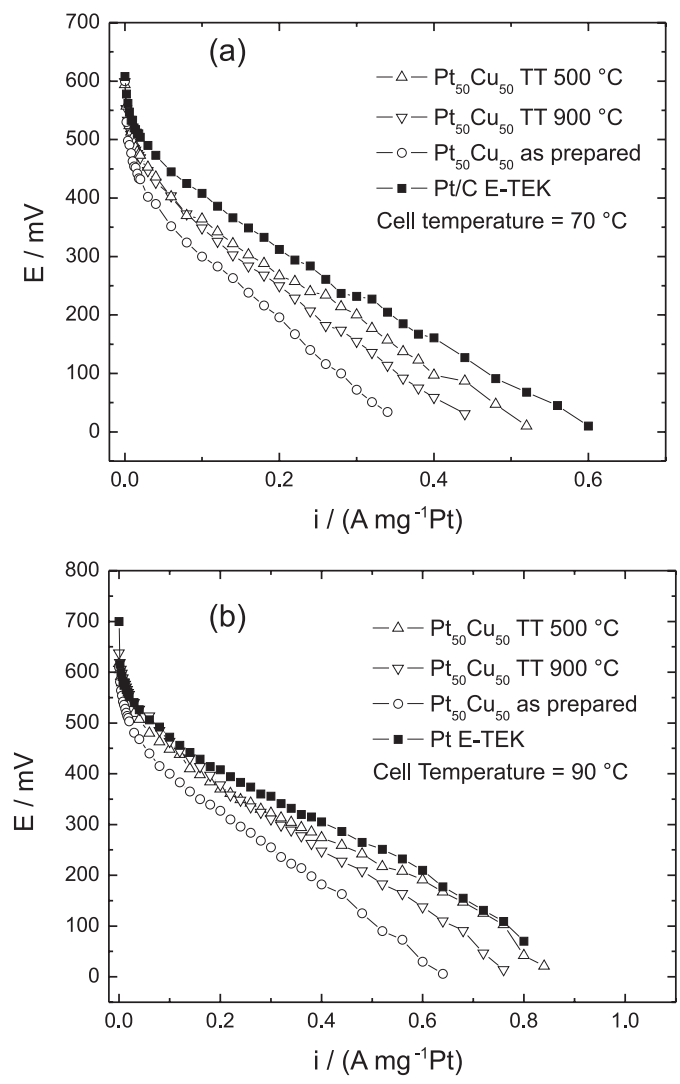

Figure 13. Cell potential vs. current density in a DMFC, in terms of MA. Cathode $\mathrm{Pt}_{50} \mathrm{Cu}_{50}$ as prepared; thermally treated at 500 and $900{ }^{\circ} \mathrm{C}$ in $\mathrm{Ar} / \mathrm{H}_{2}$ 4:1 for $1 \mathrm{~h}$. Anode $\mathrm{Pt}_{50} \mathrm{Ru}_{50}$ from E-TEK. $1 \mathrm{~mol} \mathrm{~L}^{-1}$ methanol. (a) $70{ }^{\circ} \mathrm{C}$; (b) $90{ }^{\circ} \mathrm{C}$

DMFC for the thermally treated $\left(\mathrm{T}=500{ }^{\circ} \mathrm{C}\right)$ catalysts is shown, in terms of MA, in Figure 16 as a function of $\mathrm{Cu}$ content. The best performance is observed for the $\mathrm{Pt}_{70} \mathrm{Cu}_{30}$ catalyst, but this is similar to that of pure $\mathrm{Pt}$, for both 70 and $90{ }^{\circ} \mathrm{C}$.

\section{$P t-P d-C u / C$ catalysts}

As in the case of the Pt-Cu catalysts, the best performance in terms of MA (the one of practical importance) of the cathode catalysts incorporating palladium was obtained with those catalysts thermally treated at $500{ }^{\circ} \mathrm{C}$, and the polarization curves obtained for the other catalysts are not shown.

Figures $17 \mathrm{a}$ and $17 \mathrm{~b}$ show the polarization curves in terms of MA for the Pt-Pd-Cu catalysts thermally treated at $500{ }^{\circ} \mathrm{C}$. It can be seen from Figure 17 that the best performance was obtained with the $\mathrm{Pt}_{50} \mathrm{Pd}_{40} \mathrm{Cu}_{10}$ catalyst, even though the specific area of this catalyst is smaller than that of the $\mathrm{Pt}_{60} \mathrm{Pd}_{20} \mathrm{Cu}_{20}$ catalyst thermally treated at the same temperature. Figures $18 \mathrm{a}$ and $18 \mathrm{~b}$ show the polarization curves in terms of the SA for the Pt-Pd-Cu catalysts thermally treated at $500^{\circ} \mathrm{C}$. The $\mathrm{Pt}_{50} \mathrm{Pd}_{40} \mathrm{Cu}_{10}$ catalyst shows the best performance in terms of SA, and that is why it has
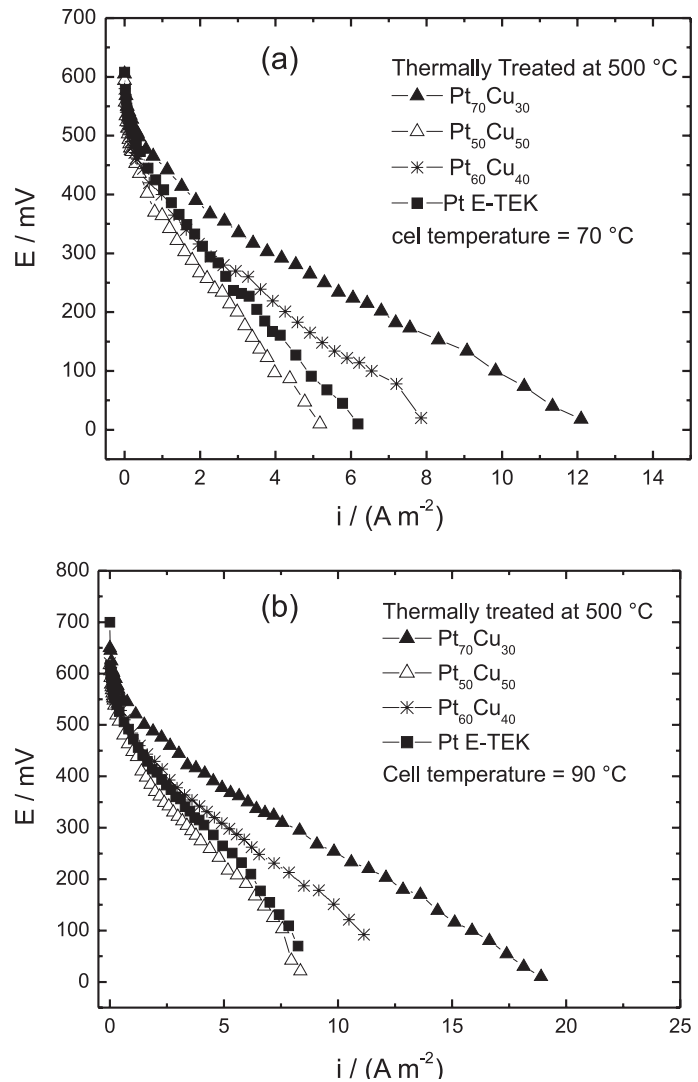

Figure 14. Cell potential vs. Current density in a DMFC, in terms of SA. Cathode $\mathrm{Pt}_{50} \mathrm{Cu}_{50} \mathrm{Pt}_{60} \mathrm{Cu}_{40}$ and $\mathrm{Pt}_{70} \mathrm{Cu}_{30}$ thermally treated at $500{ }^{\circ} \mathrm{C}$ in $\mathrm{Ar} / \mathrm{H}_{2} 4: 1$ for $1 \mathrm{~h}$. Anode $\mathrm{Pt}_{50} \mathrm{Ru}_{50}$ from E-TEK. 1 mol L-1 methanol. (a) $70{ }^{\circ} \mathrm{C}$; (b) $90^{\circ} \mathrm{C}$.

a better MA even though it has a smaller specific area than the $\mathrm{Pt}_{60} \mathrm{Pd}_{20} \mathrm{Cu}_{20}$ catalyst. As the lattice parameter is similar for both catalysts $(0.388 \mathrm{~nm})$ the difference in activity can be attributed to differences in the electronic state and/or to different copper oxide contents.

It was mentioned above that the presence of some copper oxide in the catalysts can hinder methanol oxidation and favor the adsorption of molecular oxygen, improving the performance of the catalyst as cathode material in a DMFC. This, along with the electronic effects arising from the introduction of $\mathrm{Cu}$ and $\mathrm{Pd}$ into the alloy, may be the reason for the better performance of this Pt-Pd-Cu catalyst than pure Pt.

To evaluate the differences between the Pt-Cu and Pt-Pd-Cu catalysts, the polarization curves with the $\mathrm{Pt}_{60} \mathrm{Cu}_{40}$ and $\mathrm{Pt}_{60} \mathrm{Pd}_{20} \mathrm{Cu}_{20}$ catalysts in the cathode, both thermally treated at $500{ }^{\circ} \mathrm{C}$ are compared in Figures 19a and 19b at 70 and $90^{\circ} \mathrm{C}$, respectively, in terms of SA. These two catalysts were chosen for comparison because they have a similar Pt content (approximately 60 at.\%), similar lattice parameter (Table 1) and both have probably a similar dispersion on the carbon support since they were both prepared by the same method and thermally treated at the same temperature. 

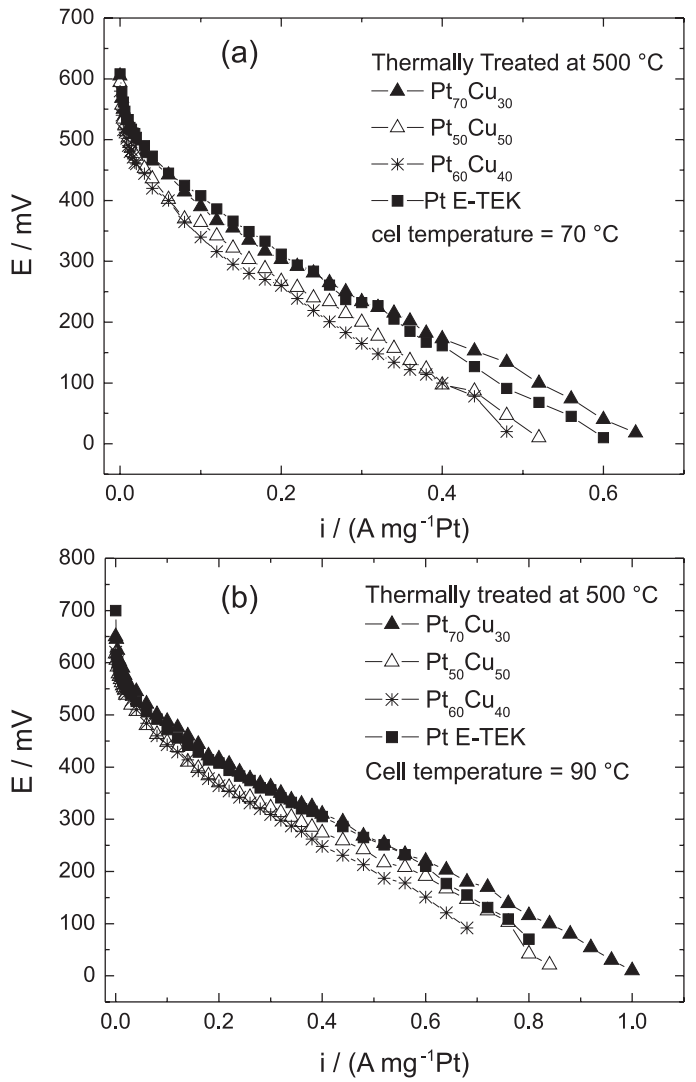

Figure 15. Cell potential vs. Current density in a DMFC, in terms of MA. Cathode $\mathrm{Pt}_{50} \mathrm{Cu}_{50} \mathrm{Pt}_{60} \mathrm{Cu}_{40}$ and $\mathrm{Pt}_{70} \mathrm{Cu}_{30}$ thermally treated at $500{ }^{\circ} \mathrm{C}$ in $\mathrm{Ar} / \mathrm{H}_{2} 4: 1$ for $1 \mathrm{~h}$. Anode $\mathrm{Pt}_{50} \mathrm{Ru}_{50}$ from E-TEK. $1 \mathrm{~mol} \mathrm{~L}^{-1}$ methanol. (a) $70{ }^{\circ} \mathrm{C}$; (b) $90{ }^{\circ} \mathrm{C}$.

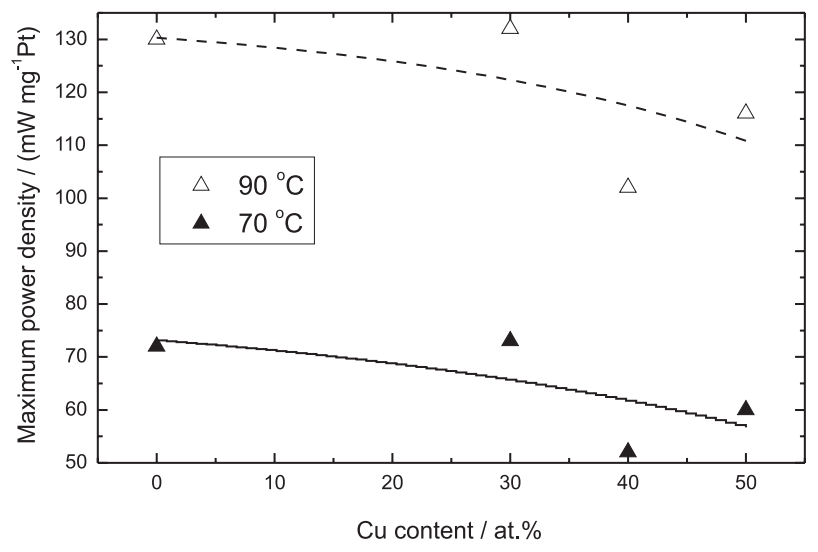

Figure 16. Effect of $\mathrm{Cu}$ content in the maximum power density of DMFCs, in terms of the MA at $70{ }^{\circ} \mathrm{C}$ and $90{ }^{\circ} \mathrm{C}$. Anode $\mathrm{Pt}_{50} \mathrm{Ru}_{50}$ from E-TEK. $1 \mathrm{~mol} \mathrm{~L}^{-1}$ methanol.

They were chosen also because in all cases the best performance was obtained with the catalysts thermally treated at $500{ }^{\circ} \mathrm{C}$. Thus, differences in performance can be attributed to particle size effects (different active surface area), electronic effects and/or differences in copper oxide content. It can be seen from Figure 19 that the $\mathrm{Pt}_{60} \mathrm{Pd}_{20} \mathrm{Cu}_{20}$
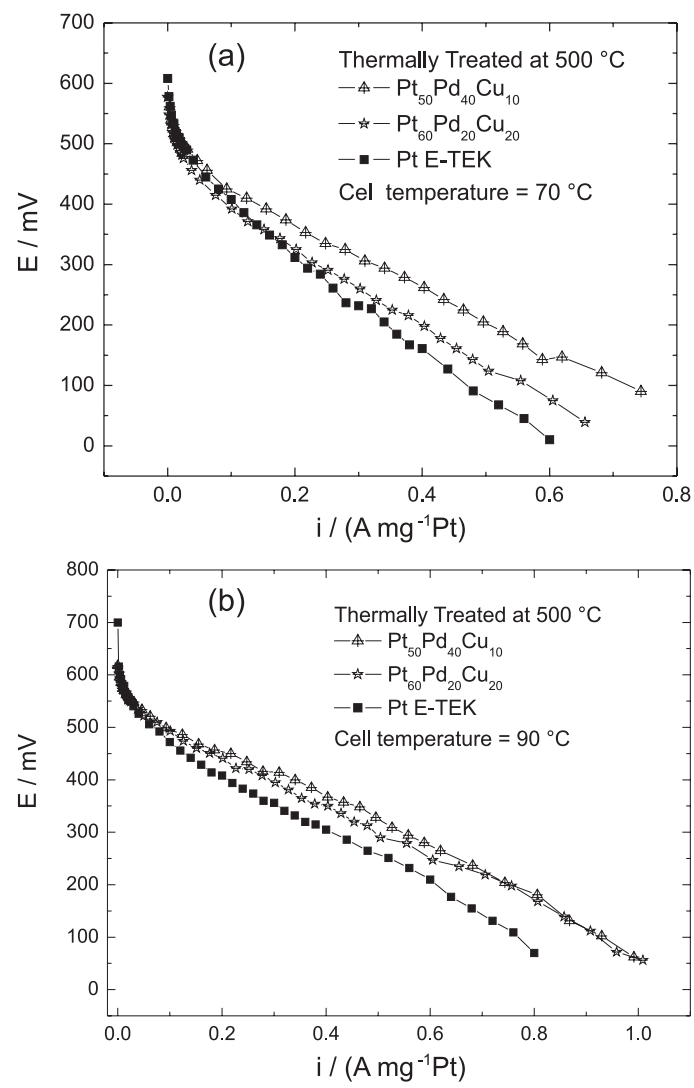

Figure 17. Cell potential vs. Current density in a DMFC, in terms of MA. Cathode $\mathrm{Pt}_{60} \mathrm{Pd}_{20} \mathrm{Cu}_{20}$ and $\mathrm{Pt}_{50} \mathrm{Pd}_{40} \mathrm{Cu}_{10}$ thermally treated at $500{ }^{\circ} \mathrm{C}$ in $\mathrm{Ar} / \mathrm{H}_{2} 4: 1$ for $1 \mathrm{~h}$. Anode $\mathrm{Pt}_{50} \mathrm{Ru}_{50}$ from E-TEK. 1 mol L-1 methanol. (a) $70{ }^{\circ} \mathrm{C}$; (b) $90^{\circ} \mathrm{C}$.

catalyst has a much better $\mathrm{SA}$ than the $\mathrm{Pt}_{60} \mathrm{Cu}_{40}$ catalyst. This is probably due to an electronic effect and to the presence of more copper oxide in the $\mathrm{Pt}_{60} \mathrm{Cu}_{40}$ catalyst. Figures 20a and 20b show the polarization curves in terms of MA for the same two catalysts. Even though the specific area of the $\mathrm{Pt}_{60} \mathrm{Pd}_{20} \mathrm{Cu}_{20}$ catalyst is almost half of that of the $\mathrm{Pt}_{60} \mathrm{Cu}_{40}$ catalyst, it shows a better performance in terms of the MA. This means that the better SA of the ternary catalyst compensates the fact that it has a larger particle size (thus, a smaller surface area), which results in a better MA. Still, it is not clear if this improvement comes from an electronic effect, a different copper oxide content, or both, which have a favorable effect on ORR activity and on the tolerance to methanol. It is clear that more detailed studies will have to be carried out.

\section{Conclusions}

Carbon supported Pt-Cu and Pt-Pd-Cu electrocatalysts were successfully prepared by reduction with sodium borohydride. Thermal treatment in a hydrogen atmosphere increases the alloyed $\mathrm{Cu}$ content, but the thermal treatment 

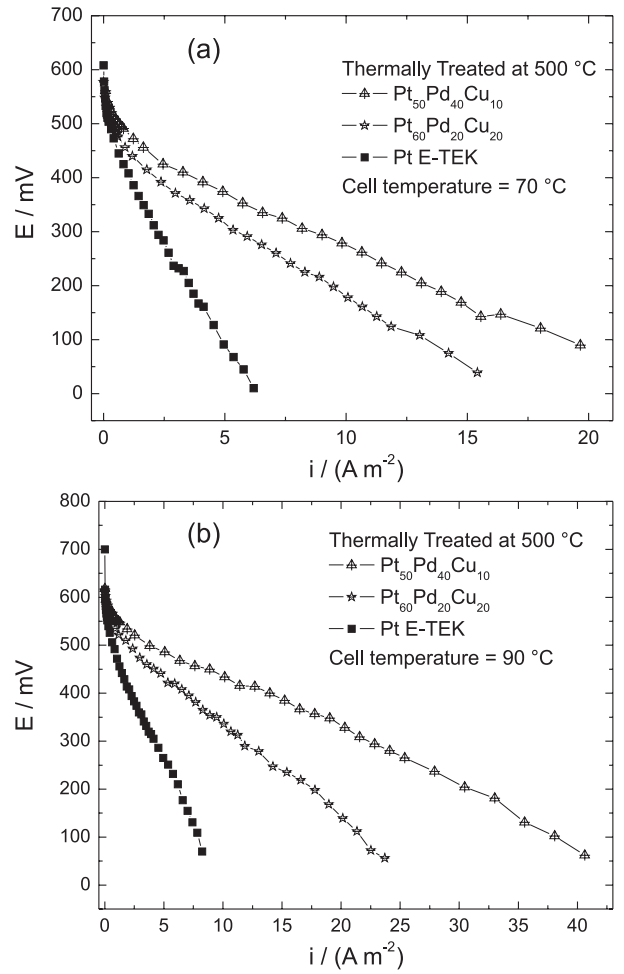

Figure 18. Cell potential vs. current density in a DMFC, in terms of SA. Cathode $\mathrm{Pt}_{60} \mathrm{Pd}_{20} \mathrm{Cu}_{20}$ and $\mathrm{Pt}_{50} \mathrm{Pd}_{40} \mathrm{Cu}_{10}$ thermally treated at $500{ }^{\circ} \mathrm{C}$ in $\mathrm{Ar} / \mathrm{H}_{2}$ 4:1 by $1 \mathrm{~h}$. Anode $\mathrm{Pt}_{50} \mathrm{Ru}_{50}$ from E-TEK. $1 \mathrm{~mol} \mathrm{~L}^{-1}$ methanol. (a) $70{ }^{\circ} \mathrm{C}$; (b) $90{ }^{\circ} \mathrm{C}$.
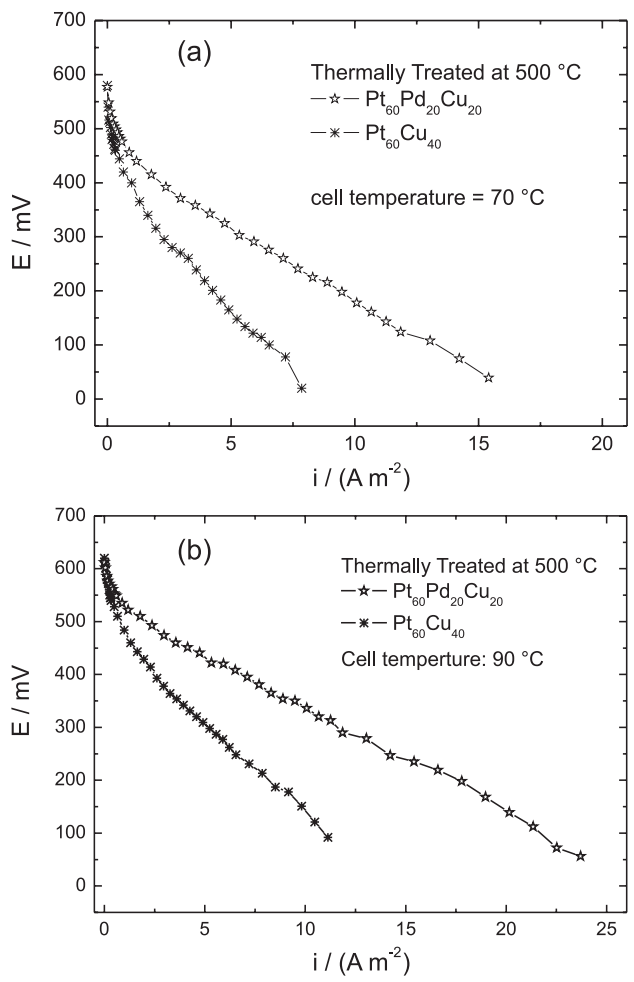

Figure 19. Cell potential vs. current density in a DMFC, in terms of SA. Cathode $\mathrm{Pt}_{60} \mathrm{Pd}_{20} \mathrm{Cu}_{20}$ and $\mathrm{Pt}_{60} \mathrm{Cu}_{40}$ thermally treated at $500{ }^{\circ} \mathrm{C}$ in $\mathrm{Ar} / \mathrm{H}_{2}$ 4:1 for $1 \mathrm{~h}$. Anode $\mathrm{Pt}_{50} \mathrm{Ru}_{50}$ from E-TEK. 1 mol L-1 methanol. (a) $70{ }^{\circ} \mathrm{C}$; (b) $90^{\circ} \mathrm{C}$.
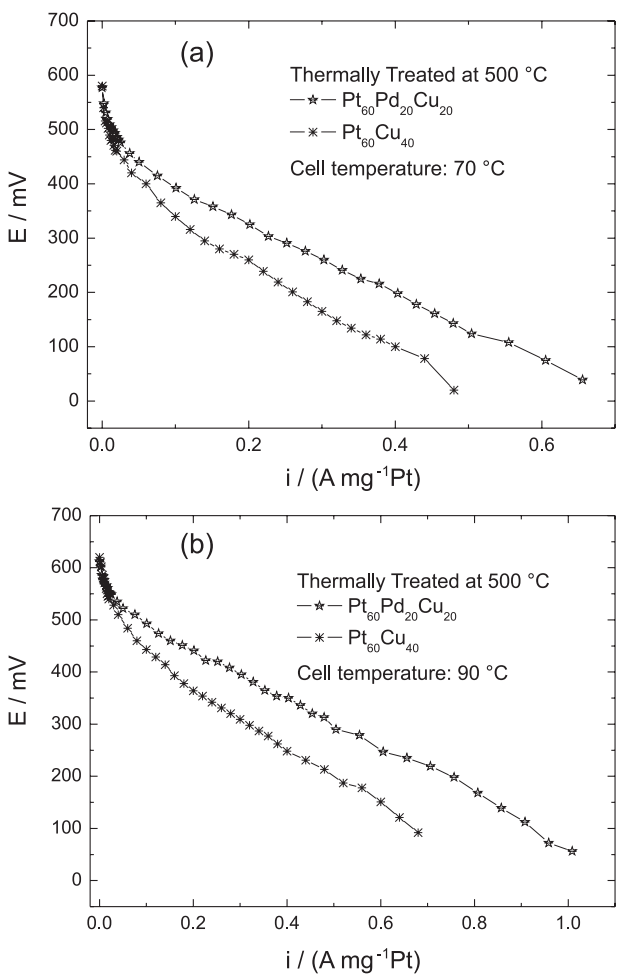

Figure 20. Cell potential vs. current density in a DMFC, in terms of MA. Cathode $\mathrm{Pt}_{60} \mathrm{Pd}_{20} \mathrm{Cu}_{20}$ and $\mathrm{Pt}_{60} \mathrm{Cu}_{40}$ thermally treated at $500{ }^{\circ} \mathrm{C}$ in $\mathrm{Ar} /$ $\mathrm{H}_{2}$ 4:1 for $1 \mathrm{~h}$. Anode $\mathrm{Pt}_{50} \mathrm{Ru}_{50}$ from E-TEK. 1 mol L${ }^{-1}$ methanol. (a) 70 ${ }^{\circ} \mathrm{C}$; (b) $90{ }^{\circ} \mathrm{C}$.

at $900{ }^{\circ} \mathrm{C}$ increases too much the particle size when the atomic ratio $\mathrm{Pt}: \mathrm{Cu}$ reaches 1 . The crystallite size decreases linearly with the increase of $\mathrm{Cu}$ content in the catalysts, but this effect is not decisive for the performance of the catalyst as a cathode in the DMFC. The amount of copper in the alloyed form and in the oxide form, carefully balanced, seems to be more important.

The incorporation of $\mathrm{Pd}$ in addition to $\mathrm{Cu}$ to $\mathrm{Pt}$ resulted in an improvement of the fuel cell performance, being the $\mathrm{Pt}_{50} \mathrm{Pd}_{40} \mathrm{Cu}_{10}$ catalyst thermally treated at $500^{\circ} \mathrm{C}$ the one who showed the best performance in terms of MA, probably due to electronic effects and because, at the thermal treatment temperature, some copper oxide is reduced without the formation of agglomerates.

The comparison of the DMFC performances with cathode catalysts with different $\mathrm{Pd} / \mathrm{Cu}$ ratio shows that the material with higher noble metal content $(\mathrm{Pt}+\mathrm{Pd})$ performs better, following the tendency observed with the $\mathrm{Pt}-\mathrm{Cu}$ binary catalysts. Also, the comparison between a $\mathrm{PtCu}$ and a Pd-modified PtCu cathode with the same Pt content showed the same tendency, i.e. having the $\mathrm{Pd}$-modified $\mathrm{PtCu}$ cathode a better performance in a DMFC. All this supports previous findings showing that the incorporation of $\mathrm{Pd}$ in a cathode catalyst improves the activity for the ORR and the tolerance to methanol. 


\section{Supplementary Information}

Supplementary data are available free of charge at http://jbcs.sbq.org.br, as PDF file.

\section{Acknowledgments}

The authors thank, the Conselho Nacional de Desenvolvimento Científico e Tecnológico (CNPq) and Fundação de Amparo a Pesquisa do Estado de São Paulo, (FAPESP) for financial assistance to the project. Thanks are also due to the Brazilian Synchrotron Light Laboratory (LNLS, Campinas, SP, Brazil) for the use of the beam line D06A-DXAS, D12A-DRX1 and HR-TEM.

\section{References}

1. Löffler, M.-S.; Natter, H.; Hempelmann, R.; Wippermann, K.; Electrochim. Acta 2003, 48, 3047.

2. Yang, B.; Manthiram, A.; Electrochem. Commun. 2004, 6, 231.

3. Schmidt, T. J.; Paulus, U. A.; Gasteiger, H. A.; Alonso-Vante, N.; Behm, R. J.; J. Electrochem. Soc. 2000, 147, 2620.

4. Baranton, S.; Coutanceau, C.; Leger, J-M.; Roux, C.; Capran, P.; Electrochim. Acta 2005, 51, 517.

5. Antolini, E.; Salgado, J. R. C.; Gonzalez, E. R.; Appl. Catal., B 2006, 63, 137.

6. Yang, H.; Alonso-Vante, N.; Léger, J-M.; Lamy, C.; J. Phys. Chem. B 2004, 108, 1938.

7. Russell, A. E.; Maniquet, S.; Mathew, R. J.; Yao, J.; Robert, M. A.; Thompsett, D.; J. Power Sources 2001, 96, 226.

8. Antolini, E.; Mater. Chem. Phys. 2003, 78, 563.

9. Santiago, E. I.; Giz, M. J.; Ticianelli, E. A.; J. Solid State Electrochem. 2003, 7, 607.

10. Teliska, M.; Murthi, V. S.; Mukerjee, S.; Ramaker, D. E.; J. Electrochem. Soc. 2005, 152, A2159.

11. Antolini, E.; J. Appl. Electrochem. 2004, 34, 563.

12. Min, M-k.; Cho, J.; Cho, K.; Kim, H.; Electrochim. Acta 2000 , 45, 4211.

13. Antolini, E.; Salgado, J. R. C.; Giz, M. J.; Gonzalez, E. R.; Int. J. Hydrogen Energy 2005, 30, 1213.

14. Maillard, F.; Martin, M.; Gloaguen, F.; Léger, J.-M; Electrochim Acta 2002, 47, 3431.

15. Carmo, M.; Paganin, V. A.; Rosolen, J. M.; Gonzalez, E. R.; J. Power Sources 2005, 142, 169.

16. Beard, C.B.; Ross, P.N.; J. Electrochem. Soc. 1990, 137, 3368.
17. Lee, J. K.; Choi, J.; Kang, S. J.; Lee, J. M.; Tak, Y.; Lee, J.; Electrochim Acta 2007, 52, 2272.

18. Nabae, Y.; Yamanaka, I.; Otsuka, K.; Appl. Catal. A 2005, 280 , 149.

19. Tseng, C.-J.; Lo, S. -T.; Lo, S. -C.; Chu, P. P.; Mater. Chem. Phys. 2006, 100, 385.

20. Xiong, L.; Kannan, A.M.; Manthiram, A.; Electrochem. Commun. 2002, 4, 898; Stassi, A.; D’Urso, C.; Baglio, V.; Di Blasi, A.; Antonucci, V.; Aricò, A. S.; Castro Luna, A. M.; Bonesi, A.; Triaca, W. E.; J. Appl. Electrochem. 2006, 36, 1143; Liu, J. H.; Jeon, M. K.; Woo, S. I.; Appl. Surf. Sci. 2006, 252, 2580; Baglio, V.; Stassi, A.; Di Blasi, A.; D’Urso, C.; Antonucci, V.; Aricò, A. S.; Electrochim. Acta 2007, 53, 1360.

21. Zhang, L.; Lee, K. C; Zhang, J.; Electrochim. Acta 2007, 52, 3088.

22. Mustain, W. E.; Kepler, K.; Prakash, J.; Electrochim Acta 2007, 52, 2102; Raughuveer, V.; Ferreira, P. J.; Manthiram, A.; Electrochem. Commun. 2006, 8, 807; Tarasevich, M. R.; Chalykh, A.E.; Bogdanovskaya, V. A.; Kuznetsova, L. N.; Kapustina, N. A.; Efremov, B. N.; Ehrenburg, M. R.; Reznikova, L. A.; Electrochim. Acta 2006, 51, 4455.

23. Salgado, J. R. C.; Antolini, E.; Gonzalez, E. R.; J. Power Sources 2005, 141, 13.

24. Rodríguez-Carbajal, J.; Phys. B 1993, 192, 55.

25. Mukerjee, S.; Srinivasan, S.; Soriaga, M.; McBreen, J.; J. Phys. Chem. 1995, 99, 4577.

26. Mukerjee, S.; Srinivasan, S.; Soriaga, M. P.; McBreen, J.; J. Electrochem. Soc. 1995, 142, 1409.

27. dos Santos, L.; Colmati, F.; Gonzalez, E. R.; J. Power Sources, 2006, $159,867$.

28. Travitsky, N.; Ripenbein, T.; Golodnitsky, D.; Rosenberg, Y.; Burshtein, L.; Peled, E.; J. Power Sources 2006, 161, 782.

29. Antolini, E.; Salgado, J. R. C.; Gonzalez, E. R.; J. Electroanal. Chem. 2005, 508, 145.

30. International Center for Diffraction Data, ICDD, PDF2 database.

31. Schneider, A.; Esch, U.; Z. Elektrochem. 1994, 50, 290.

32. Ressler, T.; Wienold, J.; Jentoft, R. E.; Neisius, T.; Günter, M. M.; Top. Catal. 2002, 1-2, 45.

33. Min, M.; Cho, J.; Cho, K.; Kim, H.; Electrochim Acta 2000 , 45,4211

Received: January 19, 2009

Web Release Date: December 3, 2009

FAPESP helped in meeting the publication costs of this article. 


\section{$\mathrm{Pt}-\mathrm{Cu} / \mathrm{C}$ and Pd Modified Pt-Cu/C Electrocatalysts for the Oxygen Reduction Reaction in Direct Methanol Fuel Cells}

\section{Emilia A. Carbonio, Flavio Colmati, ${ }^{\#}$ Eduardo G. Ciapina, Maristela E. Pereira and Ernesto R. Gonzalez*}

Instituto de Química de São Carlos, Universidade de São Paulo, CP 780, 13560-970 São Carlos - SP, Brazil
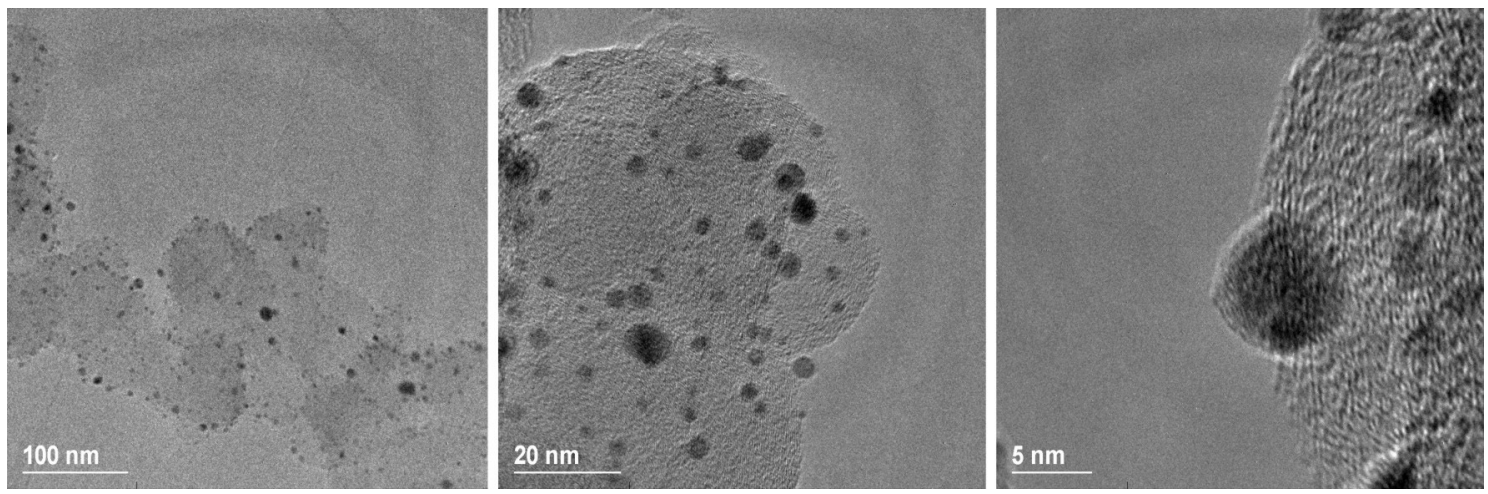

Figure S1. TEM micrographs of the $\mathrm{Pt}_{60} \mathrm{Cu}_{40} / \mathrm{C}$ catalyst prepared by chemical reduction with sodium borohydride and thermally treated at $500{ }^{\circ} \mathrm{C}$ in an $\mathrm{Ar} / \mathrm{H}_{2}$ 4:1 atmosphere.
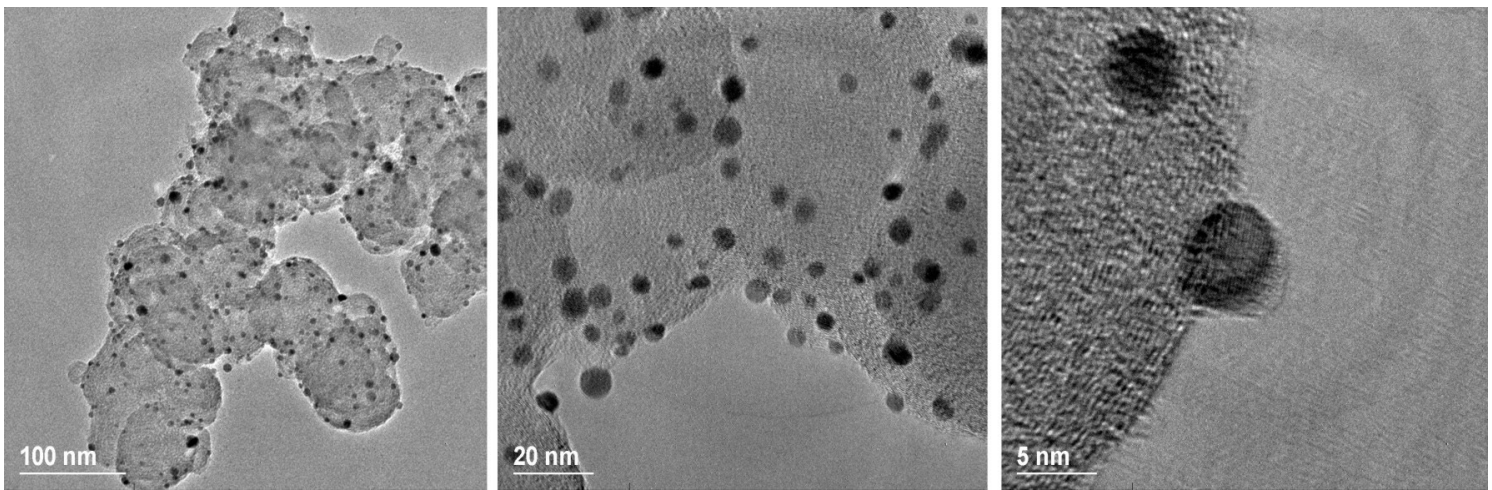

Figure S2. TEM micrograph of the $\mathrm{Pt}_{60} \mathrm{Cu}_{40} / \mathrm{C}$ catalyst prepared by chemical reduction with sodium borohydride and thermally treated at $900{ }^{\circ} \mathrm{C}$ in an $\mathrm{Ar} / \mathrm{H}_{2}$ 4:1 atmosphere.

*e-mail: ernesto@iqsc.usp.br

"Present address: Instituto de Química, Campus Samambaia, UFG, CP

131, 74001-970 Goiânia - GO, Brazil 

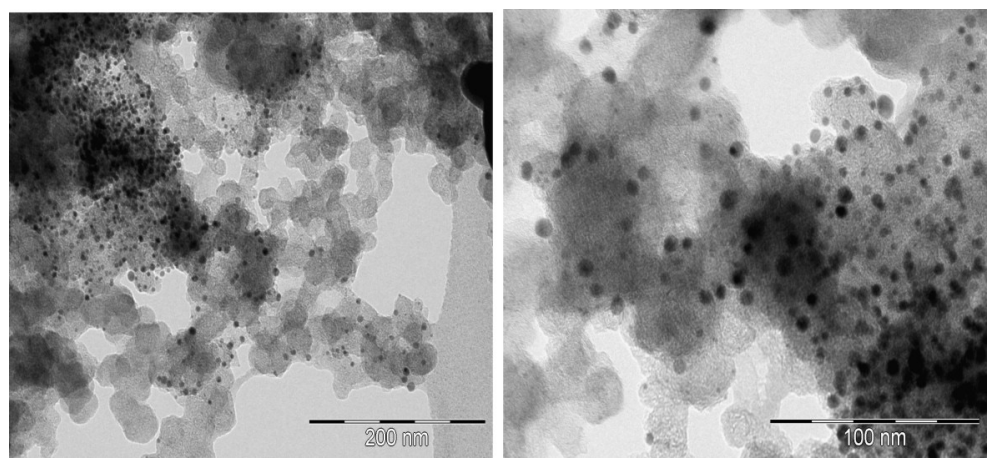

Figure S3. TEM micrograph of the $\mathrm{Pt}_{50} \mathrm{Pd}_{40} \mathrm{Cu}_{10} / \mathrm{C}$ catalyst prepared by chemical reduction with sodium borohydride and thermally treated at $500{ }^{\circ} \mathrm{C}$ in an $\mathrm{Ar} / \mathrm{H}_{2}$ 4:1 atmosphere.
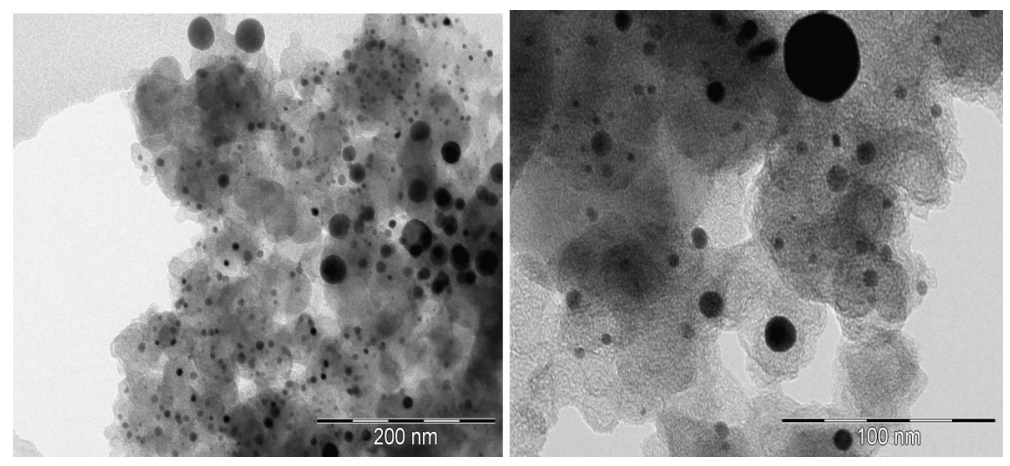

Figure S4. TEM micrograph of the $\mathrm{Pt}_{50} \mathrm{Pd}_{40} \mathrm{Cu}_{10} / \mathrm{C}$ catalyst prepared by chemical reduction with sodium borohydride and thermally treated at $500{ }^{\circ} \mathrm{C}$ in an $\mathrm{Ar} / \mathrm{H}_{2}$ 4:1 atmosphere.

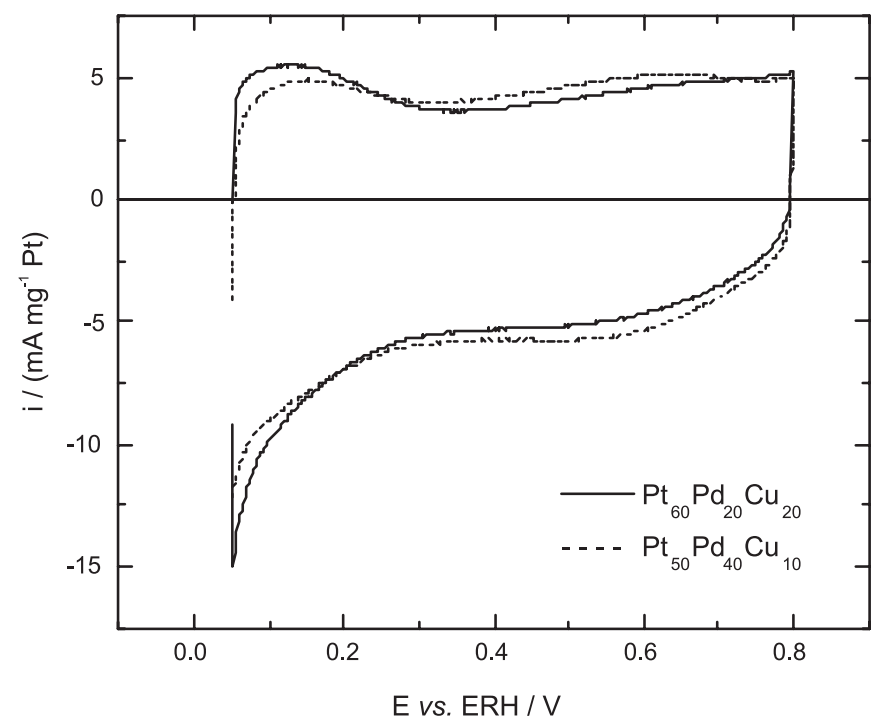

Figure S5. Cyclic voltammogram obtained in $0.5 \mathrm{~mol} \mathrm{~L}^{-1} \mathrm{H}_{2} \mathrm{SO}_{4}$ at $50 \mathrm{mV} \mathrm{s}{ }^{-1}$, for the $\mathrm{Pt}_{60} \mathrm{Pd}_{20} \mathrm{Cu}_{20}$ and $\mathrm{Pt}_{50} \mathrm{Pd}_{40} \mathrm{Cu}_{10}$ catalysts thermally treated at $900{ }^{\circ} \mathrm{C}$; Pt loading of $56 \mu \mathrm{g} \mathrm{cm}^{-2}$. (Voltammetric profiles stabilized after 20 cycles). 